\title{
Earth-based mortars for repair and protection of rammed earth walls. Stabilization with mineral
}

\section{binders and fibers}

Journal of Cleaner Production, https://doi.org/10.1016/j.jclepro.2017.11.170

\author{
Maria Idália Gomes ${ }^{1}$, Paulina Faria ${ }^{2}$, Teresa Diaz Gonçalves ${ }^{3}$
}

\begin{abstract}
${ }^{1}$ Assistant Professor, Civil Engineering Department, Lisbon Engineering Superior Institute (ISEL), Lisbon Polytechnic Institute (IPL), Rua Conselheiro Emídio Navarro 1, 1959-007 Lisbon, Portugal, idaliagomes@dec.isel.pt

2 Associate Professor, CERIS and Civil Engineering Department, NOVA University of Lisbon (FCT NOVA), Campus da Caparica, 2829-516 Caparica, Portugal, paulina.faria@fct.unl.pt

${ }^{3}$ Research Officer, Materials Department, National Laboratory for Civil Engineering (LNEC), Av. do Brasil 101, 1700-066 Lisbon, Portugal, teresag@1nec.pt
\end{abstract}

\section{Highlights}

- Rammed earth wall may suffer degradation with natural ageing and can be repaired with earth-based mortars

- Environmental performances of earthen mortars are substantially better than cementitious mortars but their physical properties are not well known

- The influence of additions of binders and hemp fibers in earth mortars is assessed

- The additions of the hemp fibers decreases thermal conductivity and drying capacity

- The addition of the binders increases capillarity, decreases the drying and is not significant for mechanic properties.

\begin{abstract}
The use of earth as a building material offers many advantages in terms of sustainability: it is a natural material, most probably non-toxic and ecological, with low energy intensity, low carbon emissions and recyclable. Earth-based mortars are re-gaining its place as building materials for plastering, rendering and repair of earthen walls, not only in the sustainable context but also in terms of efficiency. However, the scientific knowledge about these mortars is still scarce. In particular, the opinions regarding the effects of adding fibers or mineral binders as stabilizers, to improve the performance of the mortar, are contradictory. The study presented in this article is intended to advance the knowledge about the effects of adding low amounts of hemp fibers,
\end{abstract}


hydrated air lime, hydraulic lime, natural cement and Portland cement on the mechanical (flexural and compressive strength, dynamic modulus of elasticity), physical (shrinkage, thermal conductivity, porosity) and hydric (water absorption under low pressure, capillary water absorption, drying) characteristics of mortars formulated with different earth materials. Results show that the addition of the fibers decreases the thermal conductivity of the mortars, which is remarkably good for the mortars made from clayey soil, and slowers the drying of the mortars. They also show that adding the mineral binders will negatively affect the hydric behaviour of the mortars: the water absorption coefficient increases and the drying become slower as the percentage of binder increases. In addition, the use of these binders has no significant effect on the flexural and compressive strength of the mortar.

Keywords: Clayish earth; Mortar; Lime; Cement; Hemp fiber; Laboratory characterization

Contact of corresponding author: idaliagomes@dec.isel.pt

\section{Introduction}

Agenda 21 (UN, 1992) in relation to sustainable construction identified that the biggest challenge for the construction industry is to improve environmental parameters, and rethink the construction process from the perspective of sustainable development. The role played by buildings should be highlighted given that they contribute to degradation of the environment, and are responsible for $50 \%$ of global consumption of fossil fuels and 50\% of greenhouse gas emissions (Smith, 2005). According to the United Nations Environment Programme in 2009 (UNEP SBCI, 2009), globally buildings are responsible for $25-40 \%$ of energy consumption, $30-40 \%$ of $\mathrm{CO}_{2}$ emissions and $30 \%$ of materials and minerals extracted from deposits. Gustavsson and Joelsson (2010) also mention the Third Assessment Report on Climate Change which states that in Europe the housing sector accounts for a large part of primary energy use, generating $\mathrm{CO}_{2}$ emissions and a negative environmental impact.

The use of earth as a building material offers many advantages in terms of sustainability: it is natural, most probably non-toxic and ecological, with low energy intensity, low carbon emissions; reusable, recyclable (particularly when unstabilized) and, in most cases, locally available within a short distance from the construction site. Earth is often obtained as a waste in construction sites, 
reducing costs and energy for transportation and production. It is also important to refer that earthbased plasters may also contribute to indoor air quality since clay can act as a passive removal material, lowering indoor ozone concentrations, and therefore lowering the probability of occurrence of indoor ozone reaction with other building materials (Lima and Faria, 2016). Earth as a construction material act as a moisture buffer, contributing to balance the relative humidity of the indoor environment of buildings (Minke, 2006; Maddison et al., 2009; Liuzzi et al., 2013; Lima et al., 2016).

Although earth is one of the most widely used building materials around the world, it is also one of the most vulnerable. It is known that the use of earth as a building material may have problems when having direct contact with water and even the testing procedures to assess that type of performance need to be carefully defined (Gomes et al., 2016a). The susceptibility for biological development may be another question to deal with and, at least for an ilitic earth, stabilization with a low content of air lime, although decreasing the mechanical strength, contributed to decrease the biological development of earth-based plasters (Santos et al., 2017). Old masons say that air limeearth mortars were used, by mixing air lime with local grinded earth, particularly to obtain less expensive renders. But the characteristics of air lime-earth mortars only recently became to be studied (Faria et al. 2013; Faria, 2016). The microstructure of lime-earth mortars have been studied (Faria, 2016) and, in the case of lime mortars, related with carbonation (Lawrence et al., 2007).

In this article, the case of rammed earth, which is one of the most used earth building techniques, will be dealt with.

Rammed earth walls require exterior (at least after some time of exposure) and interior protection that is traditionally provided by a sacrificial render and plaster, which requirements are defined in EN 998-1 (2016). However, old rammed earth buildings often lack appropriate maintenance of these sacrificial layers, due to economic reasons. This allows a progressive erosion of the surface which, in the most extreme cases, leads to a total exposure and further decay of the rammed earth itself. Unrendered rammed earth surfaces are also found in contemporaneous architecture, usually 
due to aesthetic choices or, sometimes, for social reasons - so that the specificity of the wall can be seen and recognized. These exposed areas need repair after some years.

Repair of rammed earth walls can therefore consist in the application of a new render, repair of an existing render or repair of the surface of rammed earth. In any case, this type of conservative interventions is done by the application of mortars. And, to ensure a better compatibility with the earth wall, earth mortars are increasingly considered for this purpose. Indeed, current mortars and, in particular, cement mortar, are inadequate for earth buildings, since they are quite rigid and do not promote an appropriate exchange of water vapour. As a result, detachment between the different materials occurs (McHenry, 1984; Warren, 1999; Boussalh et al., 2004; Walker et al., 2005), after degradation of the thickness of the wall itself, with lack of cohesion. Cement-based mortars provide only temporary protection for earth walls and, in long-term, can be potentially destructive. Furthermore, their use intensifies moisture-related problems (Boussalh et al., 2004). Cement-based mortars and earth walls also have different thermal expansion coefficients (McHenry, 1984), another factor that leads to the separation of the two materials.

In the last decade and mainly due to ecological reasons (Mélia, 2015), earth mortars are also being studied and applied as eco-efficient mortars for plastering interior walls made with common masonry materials (Darling et al., 2012; Faria et al., 2014). Although plasters and renders provide a small contribution for thermal resistance of walls because of their low thickness $(1-3 \mathrm{~cm})$, the thermal conductivity of earth-based mortar can only be compared with cement-based mortars when they are formulated with high contents of insulation aggregates, like cork granules (Brás et al., 2013).

Despite this wide interest, earth mortars are rarely tackled in normative documents. Furthermore, in the few of such documents that address earth mortars, as it is the case of Lehmbau Regeln, these are usually treated in a very general way (Schroeder and Ziegert, 2008). In fact, only in 2013 two standards specific for earth mortars came into force, one concerning plasters (DIN 18947, 2013) and the other masonry mortars (DIN 18946, 2013). In addition, both the documents previously mentioned cover only the case of unstabilized mortars. The New Zealand Standard SNZ 4298 
(1998) mentions that soil based mortars may be unstabilized or stabilized with cement, hydrated lime or bitumen. However, for example in rammed earth construction it is possible to use soil without stabilization or to include Portland Cement to enhance the structural and durability qualities of walls (SNZ 4298, 1998). Also the Zimbabwe Standard SAZS 724 (2001) mentions that is possible to add cement, lime, pozzolans and bitumen to earth plaster. New Mexico Code (2006) refer that exterior of unstabilized rammed earth soil shall be protected with approved stucco systems. For Australian Earth Building Handbook (Walker and Australia, 2002) the main problem with cement render when applied in unstabilized earth walls is the long-term integrity that is not ensured.

Earth mortars use clay as binding agent, although chemical stabilizers - mineral binders like lime or cement - are also allowed or even recommended by several authors (Ashurst and Ashurst, 1995; SAZS 724, 2001; Minke, 2006; New Mexico Code, 2006). For these authors, this addition can improve certain properties, such as strength and durability. But these opinions are not widely accepted, in particular in what concerns the use of cement, which is the most common stabilizer. Indeed, some studies indicate that the addition of cement to earth mortar renders is not appropriate in the case of earth buildings (Warren, 1999) and represents a colossal mistake that engenders major long-term problems (McHenry, 1984; Walker and Australia, 2002; Guelberth and Chiras, 2003). Jiménez Delgado and Guerrero (2006) and Walker et al. (2005) are more specific and advise against the use of mortars with a high content of cement in unstabilized earth walls. Nevertheless, it is often noted in the literature that the use of mineral stabilizers, cement included, is a common practice.

In spite of this discussion (and probably at its root), the effects that mineral binders may have on the characteristics of earth mortars are still poorly studied. Also the use of hemp fibers is rarely study. A review article of fibers used in earth construction only found two studies using hemp fibers (Laborel-Préneron et al., 2016) and a study justifying the use of hemp lime renders in earth constructions (Arizzi et al., 2015). But the research in the area of fibers and other bioaggregates for construction materials is increasing, including the characterization of the bioaggregates such as hemp fibers (Laborel-Préneron et al., 2017). 
Therefore, to foster a better understanding of the properties of earth mortars without and with binder stabilization and hemp fibers, an experimental work was carried out, based on the following tests on mortars: workability in fresh state; physical properties as linear and volumetric shrinkage, thermal conductivity and dry density, porosity and porosimetry; hydric properties as water absorption under low pressure, capillary water absorption and drying; mechanical properties like dynamic modulus of elasticity, compressive and flexural strength.

\section{Materials}

The experimental mortars were formulated with four types of earth. Three of them were collected in situ (Av, PD and VC) from non-deteriorated parts of unstabilized rammed earth walls of old buildings. The fourth is a commercial earth composed mainly of clay, henceforward designated as reference-earth (RE). The characteristics of the collected earths and the location of the respective buildings are described elsewhere (Gomes et al., 2014). The reference-earth is also fully characterized elsewhere (Gomes et al. 2012a, 2012b).

The crystalline compounds of the four earths were analysed by X-ray diffraction (XRD) using a Philips X'Pert diffractometer with Fe-filtered cobalt Ka radiation, operating at $35 \mathrm{kV}$ and $45 \mathrm{~mA}$. Powder diffraction data were collected in the range $3^{\circ}-74^{\circ}(2 \theta)$ in steps of $0.05^{\circ} / \mathrm{s}(2 \theta / \mathrm{s})$. HighScore X'Pert software was used to compare the experimental peaks with the ICDS database.

In several samples, minerals were detected with reflective characteristics in the $7^{\circ} 2 \theta$ zone. This means that they could correspond to smectite, which is an expansive mineral, or to chlorite which has a low specific surface and hence, it is considered to be a non-swelling clay. Therefore, the samples were subjected to treatment with ethylene glycol, in order to screen for the presence of smectite. Unlike chlorite, smectite expands to about $6^{\circ} 2 \theta$ after treatment with ethylene glycol. For all the samples, the results were above the threshold established in the testing protocol, which allowed to dismiss the presence of minerals from the smectite family.

Table 1 shows that the main clay minerals present in all the earth samples are chlorite and kaolinite. These types of clay generally show small volumetric changes in the presence of water (Velde, 
2008). Mica/illite was also detected in all the materials. This crystalline compound may correspond to different types of clay minerals which, however, all present small volumetric changes in the presence of water.

\section{Table 1}

XRD mineralogical composition of the fine fraction of the four earths used in mortars.

\begin{tabular}{|c|c|c|c|c|c|c|c|c|c|}
\hline \multirow{2}{*}{$\begin{array}{l}\text { Earth/Crystalline } \\
\text { compounds }\end{array}$} & \multirow{2}{*}{$\begin{array}{l}\text { Quartz } \\
+++\end{array}$} & \multirow{2}{*}{$\begin{array}{l}\text { Feldspar } \\
+/++\end{array}$} & \multicolumn{2}{|c|}{ Mica/illite Chlorite } & \multirow{2}{*}{$\begin{array}{l}\text { Kaolinite } \\
\text { Trc }\end{array}$} & \multirow{2}{*}{$\begin{array}{l}\text { Goethite } \\
\text { - }\end{array}$} & \multirow{2}{*}{$\begin{array}{l}\text { Anatase } \\
-\end{array}$} & \multicolumn{2}{|c|}{ Amphibole Hematite } \\
\hline & & & + & $\operatorname{Trc}$ & & & & $\operatorname{Trc}$ & $?$ \\
\hline PD & +++ & $\operatorname{Trc}$ & $+/++$ & $?$ & $+/++$ & - & - & - & + \\
\hline $\mathrm{VC}$ & +++ & Trc/t & ++ & + & + & - & - & - & $?$ \\
\hline RE & +++ & $\operatorname{Trc}$ & $\operatorname{Trc}$ & $?$ & ++ & + & $+/ \operatorname{Trc}$ & - & - \\
\hline
\end{tabular}

Notation: +++ high proportion; ++ intermediate proportion; + low proportion; Trc traces; ? doubts on the presence; - not detected

After disaggregation of the earth samples, the particle size distribution (Figure 1) was determined following the methods indicated in LNEC Specifications E196 (1966) and E239 (1970).

The compositions of the twenty nine formulated mortars are presented in Table 2. In the table, the mortars are identified by the letter M (mortar) followed by an acronym that designates the type of earth they were made from (Av, PD, VC or RE). Whenever binder additions exist, a letter identifying the type of binder is also added in the end.

The four types of earth were previously corrected by addition of a siliceous washed sand (mainly composed by quartz) in the range 0.6 to $2.0 \mathrm{~mm}$. This sand was added in different proportions, taking into account the percentage and type of clay present in the earth. The main objective was to reduce the drying shrinkage of the mortars. The particle size distribution of this sand was determined following the method indicated in LNEC Specification E196 (1966). The five particle size distribution curves can be seen in Figure 1. 


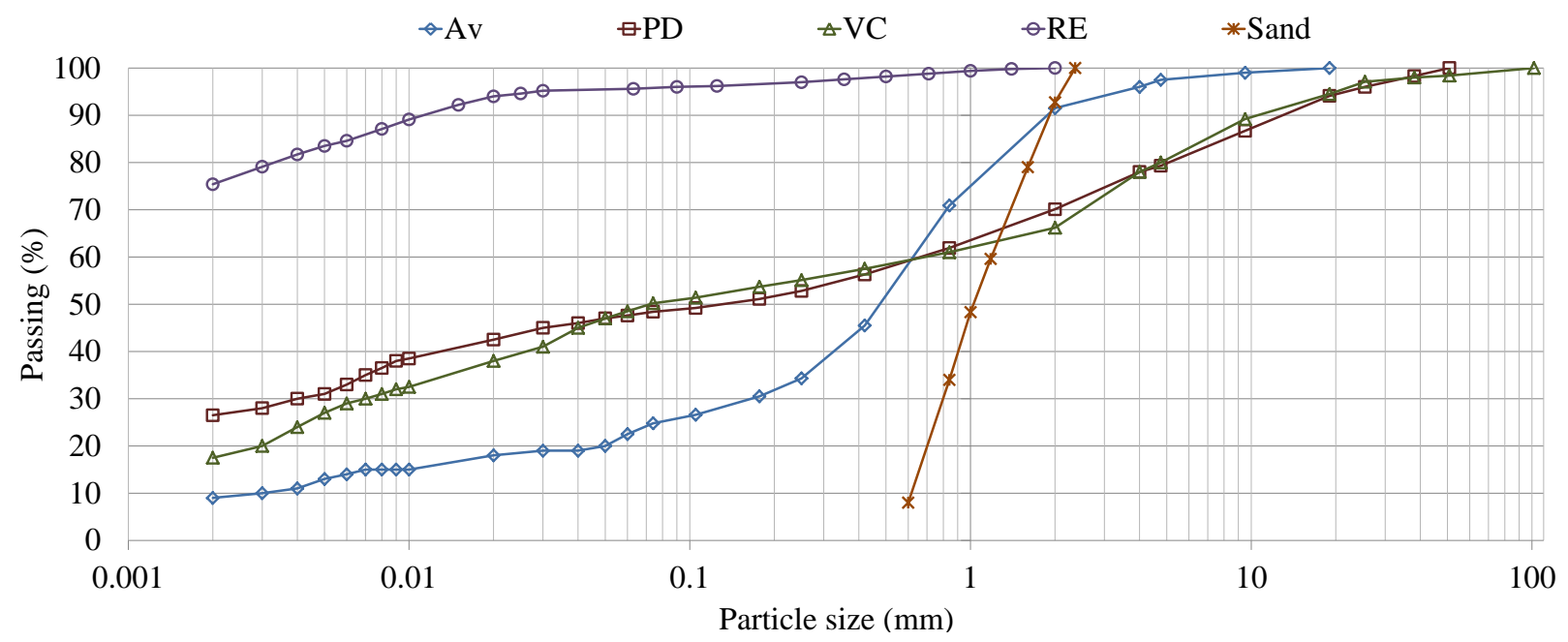

Figure 1. Particle size distribution of the three earths collected in situ (Av, PD and VC), the reference-earth (RE) and the sand

Binders and fibers were added only to the MRE mortars, as seen in Table 2. The proportions were:

- $0 \%, 5 \%, 10 \%$ and $15 \%$ of powder hydrated air lime CL90-S from Lusical (CL), hydraulic lime HL5 from Secil (HL) (EN 459-1, 2015), Portland cement CEM II BL 32.5 N from Secil (PC) (EN 197-1, 2011) or natural cement (NC) provided by ROCARE EU-Project (2012);

- $0 \%$ or $5 \%$ of hemp fibers, cut with average dimensions in about $2.5 \mathrm{~cm}$ and diameter $0.2 \mathrm{~cm}$ $(\mathrm{F})$.

These percentages are given in relation to the weight of the clayish earth, i.e., of the earth material before its correction with sand.

Table 2

Composition of the mortars.

\begin{tabular}{|c|c|c|c|c|c|c|c|c|}
\hline \multirow{2}{*}{ Earth based mortars } & \multirow{2}{*}{ Designation } & \multirow{2}{*}{$\begin{array}{l}\text { Weight } \\
\text { proportions } \\
\text { (clay:sand) }\end{array}$} & \multirow{2}{*}{$\begin{array}{l}\text { Volumetric } \\
\text { proportion } \\
\text { (clay:sand) }\end{array}$} & \multicolumn{4}{|c|}{ Stabiliser $(\%)^{*}$} & \multirow{2}{*}{$\begin{array}{l}\text { Fibers } \\
(\%)^{*}\end{array}$} \\
\hline & & & & $\mathrm{CL}^{(1)}$ & $\mathrm{HL}^{(2)}$ & $\mathrm{PC}^{(3)}$ & $\mathrm{NC}$ & \\
\hline Local earth Av & MAv & $1: 0$ & $1: 0$ & - & - & - & - & - \\
\hline Local earth PD & MPD & $1: 1.9$ & \multirow{2}{*}{$1: 1.5$} & - & - & - & - & - \\
\hline Local earth VC & MVC & $1: 2.4$ & & - & - & - & - & - \\
\hline Reference-earth & MRE & \multirow{5}{*}{$1: 3.8$} & \multirow{5}{*}{$1: 3$} & - & - & - & - & 0,5 \\
\hline $\begin{array}{l}\text { Reference-earth with } \\
\text { hydrated air lime }\end{array}$ & MRE_CL & & & $5,10,15$ & - & - & - & 0,5 \\
\hline $\begin{array}{l}\text { Reference-earth with } \\
\text { hydraulic lime }\end{array}$ & MRE_HL & & & - & $5,10,15$ & - & - & 0,5 \\
\hline $\begin{array}{l}\text { Reference-earth with } \\
\text { Portland cement }\end{array}$ & MRE_PC & & & - & - & $5,10,15$ & - & 0,5 \\
\hline $\begin{array}{l}\text { Reference-earth with } \\
\text { natural cement }\end{array}$ & MRE_NC & & & - & - & - & $5,10,15$ & 0,5 \\
\hline
\end{tabular}

* Percentages by weight in relation to the reference earth.

${ }^{(1)}$ EN 459-1 (2015), CL 90-S; ${ }^{(2)}$ EN 459-1 (2015), HL5 and ${ }^{(3)}$ EN 197-1 (2011), CEM II/BL 32.5 N. 


\section{Test methods}

The mortars were characterized in the fresh state. Prismatic Alcock test samples $500 \mathrm{~mm}$ x $40 \mathrm{~mm} \times$ $40 \mathrm{~mm}$ and prismatic samples with $160 \mathrm{~mm}$ x $40 \mathrm{~mm}$ x $40 \mathrm{~mm}$ were prepared with each mortar, as well as cubic samples with $50 \mathrm{~mm}$ side. They were conditioned for 90 days at $20 \pm 2^{\circ} \mathrm{C}$ and $50 \pm 5 \%$ $\mathrm{RH}$ before being used for hardened characterization. All the tests carried out in the experimental campaign, to characterize both materials and mortars, standards of test procedures that were followed and equipments used, can be visualized in Table 3.

To obtain the earth-based repair mortars (MAv, MPD, MVC and MRE) the four types of earth were prepared as follows, before mixing:

(i) for the three types of earth $(\mathrm{Av}, \mathrm{PD}, \mathrm{VC})$ taken from old rammed earth buildings, only the material that, by wet sieve (E196, 1966 and E239, 1970), passed through a 2 mm sieve ( $\mathrm{n}^{\circ}$. 10 ASTM), was used; after wet sieving, the material was decanted, dried in a ventilated oven at $40^{\circ} \mathrm{C}$, ground with a jaw crusher and then a splitter was used to homogenize the mixture;

(ii) the reference-earth (RE) already had a large percentage of clay; therefore, it was only necessary to ground, disaggregate and then homogenize the material as described above.

The method used to prepare the mixtures is fully described in Gomes et al. (2016b, 2013). This preparation followed as closely as possible standard EN 196-1 (2016). However, because this standard is not specific neither for earth-based mortars nor for repair mortars, some adjustments had to be made. One of the major differences was the increase in mixing time in relation to that specified in the standard, which was necessary because the mixtures had a large percentage of clay. 
Table 3

Test methods carried out in the experimental campaign.

\begin{tabular}{|c|c|c|c|c|}
\hline Characterization & Material/specimens & $\begin{array}{l}\text { Characterization } \\
\text { tests }\end{array}$ & Standard_document/Equipment & $\begin{array}{c}\text { Number of tests } \\
\text { performed by material }\end{array}$ \\
\hline \multirow[t]{2}{*}{$\begin{array}{l}\text { Materials ( Av, PD, } \\
\text { VC and RE) }\end{array}$} & \multirow{2}{*}{$\begin{array}{l}\text { Rammed earth material } \\
\text { colleted in situ, } \\
\text { Av, PD, VC } \\
\text { and } \\
\text { reference-earth, RE }\end{array}$} & $\begin{array}{l}\text { Mineralogical } \\
\text { composition by } \\
\text { XRD }\end{array}$ & 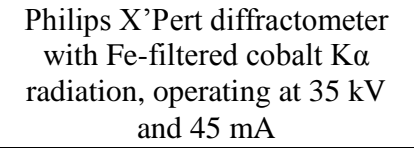 & One test \\
\hline & & $\begin{array}{l}\text { Particle size } \\
\text { distribution }\end{array}$ & $\begin{array}{l}\text { LNEC Specifications E196 } \\
\text { (1966) and E239 (1970) }\end{array}$ & One test \\
\hline \multirow{2}{*}{$\begin{array}{c}\text { Fresh mortars } \\
\text { (MAv, MPD, MVC } \\
\text { and MRE) }\end{array}$} & \multirow{2}{*}{ Mortars } & Flow table & EN 1015-3 (1999) & $\begin{array}{l}\text { Average value of two } \\
\text { tests }\end{array}$ \\
\hline & & Wet bulk density & EN 1015-6 (1998) & $\begin{array}{l}\text { Average value of two } \\
\text { tests }\end{array}$ \\
\hline \multirow{9}{*}{$\begin{array}{l}\text { Hardened mortars } \\
\text { (MAv, MPD, MVC } \\
\text { and MRE) }\end{array}$} & $\begin{array}{l}\text { Prismatic specimens } \\
300 \times 30 \times 30(\mathrm{~mm})\end{array}$ & $\begin{array}{l}\text { Linear and } \\
\text { volumetric } \\
\text { shrinkage }\end{array}$ & $\begin{array}{c}\text { Alcock test by Keable (1996) } \\
\text { and Walker and Australia } \\
(2002)\end{array}$ & $\begin{array}{c}\text { Average value of three } \\
\text { tests }\end{array}$ \\
\hline & $\begin{array}{l}\text { Small samples from } \\
\text { prismatic specimens- }\end{array}$ & $\begin{array}{l}\text { Porosity and } \\
\text { porosimetry }\end{array}$ & $\begin{array}{c}\text { MIP with a Micromeritics } \\
\text { Autopore IV }\end{array}$ & One test \\
\hline & \multirow{3}{*}{$\begin{array}{l}\text { Cubic specimens } \\
50 \times 50 \times 50(\mathrm{~mm})\end{array}$} & $\begin{array}{l}\text { Capillary water } \\
\text { absorption }\end{array}$ & EN 16322 (2013) & $\begin{array}{l}\text { Average value of six } \\
\text { cubic specimen }\end{array}$ \\
\hline & & Drying & EN 16322 (2013) & $\begin{array}{l}\text { Average value of six } \\
\text { cubic specimen }\end{array}$ \\
\hline & & $\begin{array}{c}\text { Water absorption } \\
\text { under low pressure }\end{array}$ & $\begin{array}{l}\text { Karsten tube test } \\
\text { EN } 16302(2013)\end{array}$ & $\begin{array}{c}\text { Average value of three } \\
\text { cubic specimen }\end{array}$ \\
\hline & \multirow{4}{*}{$\begin{array}{l}\text { Prismatic specimens } \\
160 \times 40 \times 40(\mathrm{~mm})\end{array}$} & Dry density & EN 1015-10/A1 (1999) & $\begin{array}{l}\text { Average value of six } \\
\text { prismatic specimen }\end{array}$ \\
\hline & & $\begin{array}{c}\text { Thermal } \\
\text { conductivity }\end{array}$ & $\begin{array}{l}\text { ISOMET Heat Transfer } 2104 \\
\text { with contact probe }\end{array}$ & $\begin{array}{l}\text { Average value of three } \\
\text { tests }\end{array}$ \\
\hline & & $\begin{array}{l}\text { Dynamic modulus } \\
\text { of elasticity }\end{array}$ & $\begin{array}{l}\text { Sonometer equipment } \\
\text { measuring the fundamental } \\
\text { resonance frequency } \\
\text { EN } 14146(2004)\end{array}$ & $\begin{array}{l}\text { Average value of six } \\
\text { prismatic specimen }\end{array}$ \\
\hline & & $\begin{array}{l}\text { Compressive and } \\
\text { flexural strength }\end{array}$ & EN 1015-11 (1999) & $\begin{array}{l}\text { Average value of six } \\
\text { prismatic specimen }\end{array}$ \\
\hline
\end{tabular}

Notation: XRD - X-ray diffraction; MIP- mercury intrusion porosimetry

The curing conditions are fully characterized elsewhere (Gomes et al., 2016a, 2016b). Standard EN 1015-11 (1999) focuses on the curing conditions of various types of mortar (i.e. cement, lime). However, earth mortars are not covered and, therefore, the method recommended for lime mortars was followed, with sligth adjustments. The specimens were kept in a conditioned room $\left(20 \pm 2^{\circ} \mathrm{C}\right.$ and $50 \pm 5 \% \mathrm{RH}$ ) in moulds during 14 days (the first 7 days in a sealed polyethylene bag). After that they were demoulded and remained in the same conditioned room until they reached the age of 90 days. At the end of the $28^{\text {th }}$ day the specimens with dry hydrated air lime (CL) were further subjected, for 7 days, to accelerated carbonation $-5 \% \mathrm{CO}_{2}, 21 \pm 2^{\circ} \mathrm{C}$ and $71 \pm 2 \%$ relative humidity $(\mathrm{RH})$ - to ensure complete carbonation.

For characterization of the mortars in the fresh state, the consistency by flow table (EN 1015-3, 1999) and wet bulk density (EN 1015-6, 1998) were measured. 
The mortars were also characterized in relation to their drying shrinkage. For earth materials, the linear shrinkage is commonly assessed, using the Alcock test which is also called the linear shrinkage test or shrinkage box test (SNZ 4298, 1998; Walker and Australia, 2002; Keefe, 2005; Houben and Guillaud, 2006; Lehmbau Regeln, 2009; Guillaud, 2008). The linear shrinkage of the mortars was measured following the procedure proposed by Keable (1996) and Walker and Australia (2002). However, it was observed that the shrinkage of the samples was significant not only throughout its length - the linear shrinkage - but also in the other two dimensions - volumetric shrinkage. Thus, it was done an average of four measurements, either in length and width. To carry out this test boxes made of film-faced plywood with internal dimensions of $300 \mathrm{~mm} \times 30 \mathrm{~mm} \times 30$ $\mathrm{mm}$ were manufactured. The surfaces of the box were slightly lubricated with oil to prevent adhesion. The mortars were placed in the boxes and pressed to release the entrained air. Using a palette knife the excess of mortars were skimmed off so that the surfaces became plane. The four measurements were done when the mortars were completely dry. This test method is fully characterized in Gomes et al. (2016b).

As to the characterization of the hardened mortars, it included the following methods and procedures.

The dry density in the hardened state is given by the ratio between the dry mass of each specimen and the corresponding volume, measured by a digital caliper (EN 1015-10:1999/A1:2006).

Thermal conductivity was determined using an ISOMET Heat Transfer 2104 equipment, with a 6 cm diameter contact probe API 210412 with only partial contact with the earth mortar specimens: specimens with surface area of $40 \times 160 \mathrm{~mm}$ under the probe with area of $60 \mathrm{~mm}$ diameter. Therefore comparison is only possible for similar samples.

Porosity and pore size distribution were measured by mercury intrusion porosimetry (MIP), with a Micromeritics Autopore IV. The volume of mercury that penetrates in the sample is measured as a function of pressure; low pressures ranging from $0.01 \mathrm{MPa}$ to $0.21 \mathrm{MPa}$, followed by highpressures from 0.28 MPa to 206.84 MPa, were applied. 
The capillary water absorption of the mortars was also measured. This test was performed according to EN 15801 (2009), for the water absorption coefficient, using six cubic specimens (dimension $50 \mathrm{~mm}$ ) for each type of earth mortars. Since this standard is not suitable for earth mortars, the procedures were adapted. The lateral faces of these specimens were waterproofed using a mixture with the mass proportion of $50 \%$ pitch blond and $50 \%$ beeswax. The bottom face was covered with a cotton cloth to prevent mass loss, from the specimens, during the absorption. The specimens were placed in partial immersion, about 2 to $4 \mathrm{~mm}$ above the base of the specimens. At time intervals, the samples were weighed, and then put again in the water. The increase in the mass over time was determined (Gomes et al., 2016a, 2016b). The results of this test are expressed by the capillary absorption curve, which represents the amount of water absorbed per unit area $\left(\mathrm{kg} / \mathrm{m}^{2}\right)$ as a function of the square root of elapsed time $\left(s^{1 / 2}\right)$. The slope of the most representative initial linear segment of this curve corresponds to the capillary absorption coefficient (CC). The asymptotic value of the curve is an approximation of the total amount of water absorbed by the specimen.

The drying behaviour was also evaluated. The drying test began immediately after the capillary water absorption test. The bottom of these specimens were sealed with a polyethylene sheet (Gomes et al., 2016a, 2016b). Then, the specimens were placed in a conditioned room at $20 \pm 2^{\circ} \mathrm{C}$ and $50 \pm 5 \%$ $\mathrm{RH}$ on an impermeable surface so that the drying could only occur by the top surface. The amount of evaporated water was measured by periodical weighings. The results are expressed by the drying index and the drying rate in the first drying phase (EN 16322, 2013); the latest corresponds to the slope of the initial portion of the drying curve, expressing the amount of moisture per unit area $\left(\mathrm{kg} / \mathrm{m}^{2}\right)$ as a function time (s) (EN 16322, 2013).

The Karsten tube test was used to measure the water absorption of mortars under low pressure, based on EN 16302 (2013). The dried specimens previously used for capillary and drying tests were used. The Karsten tubes were placed and secured on the top of the specimens and filled with $4 \mathrm{ml}$ of water. The water adsorbed by the material was then measured at the 5, 10, 15, 30 and 60 min.

The mechanical properties of the mortars were also studied. The dynamic modulus of elasticity was determined by measuring the fundamental resonance frequency, based on EN 14146 (2004) and 
using a Sonometer equipment for determination of the resonance frequency test apparatus. The specimens were weighed, measured and properly installed in the equipment. Six prismatic specimens of each mortar were used. Afterwards, the same specimens were subjected to compressive and flexural strength tests, following standard EN 1015-11 (1999). However, due to the low resistance of the specimens, some adjustments were made. Standard load rates of 10 and 50 $\mathrm{kN} / \mathrm{s}$ for flexural and compressive strength, respectively, were used. According to the standard, the rupture of the specimen must occur between 30 and 90 seconds both in flexural and compressive strength. However, even by using the lowest speed, $10 \mathrm{kN} / \mathrm{s}$ in flexural strength and $50 \mathrm{~N} / \mathrm{s}$ in compressive strength, it was not possible to comply with the 30 seconds required by the standard. The flexural strength (f) was determined by a three points bending test and was determined by equation $\mathrm{f}=1.5\left(\mathrm{Fl} /\left(\mathrm{bd}^{2}\right)\right)$, where $F$ corresponds to the maximum force recorded during the test, $l$ correspond to distance between the support rollers of the specimen, $b$ and $d$ may be taken as the internal mould dimensions. The compressive strength, performed on the two halves of the specimens resulting from the flexural test, corresponds to the maximum force recorded, divided by the contact area of the sample.

\section{Results and discussion}

\subsection{Characterization of the dry mortar mixes}

Figure 2 shows the particle size distribution of the dry mortar mixes made with the four types of earth, i.e., of the dry mortar mixes used for the formulation of the repair mortars according to the volumetric and weight proportions shown in Table 2. 


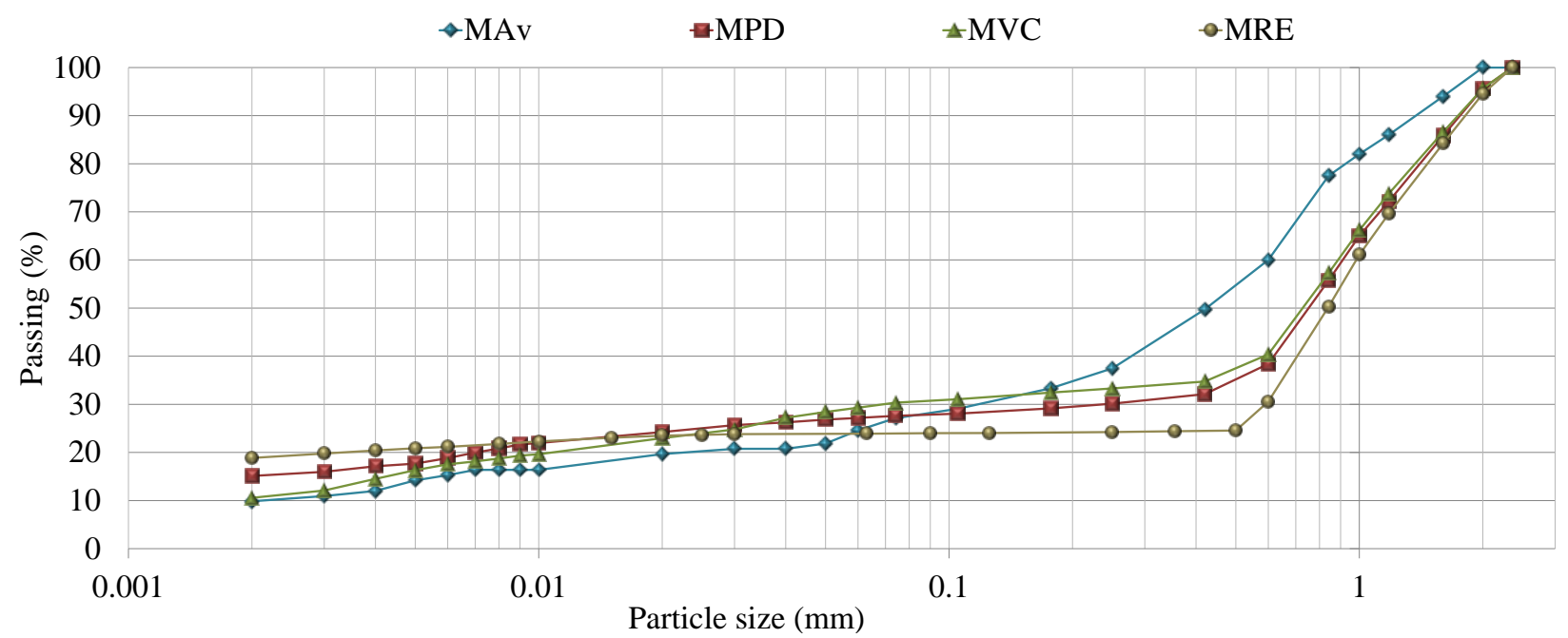

Figure 2. Particle size distribution of the four dry mortar mixes, MAv, MPD, MVC and MRE.

It can be observed that MAv is coarser than all the others mortar mixes, being MRE the finer. That justifies the fact of Mav has no addition of sand while MRE has the highest sand content.

\subsection{Characterization in fresh state}

The water content of the mortars was adjusted in order to produce a flow table consistency of the fresh mortars within the 160-176 mm interval. As shown in Gomes et al. (2012b), this interval corresponds in general to earth-based mortars with excellent workability. Table 4 shows the obtained flow values, which ranged from 159 to $177 \mathrm{~mm}$. The wet bulk density of the fresh mortars is also reported in Table 4. The mortars with hemp fibers exhibit lower bulk density which is in accordance with the lower bulk density of these fibers in comparison with the other mortar materials (Arizzi et al., 2015; Laborel-Préneron et al., 2017).

\section{Table 4}

Flow table consistency and wet density of fresh mortars, dry bulk density and thermal conductivity of hardened mortars.

Mortars MAv MPD MVC MRE

- $\quad$ CL5 CL10 CL15 HL5 HL10 HL15 PC5 PC10PC15 NC5 NC10 NC15

\begin{tabular}{llllllllllllllllll}
\hline \multirow{2}{*}{ Flow (mm) } & $\begin{array}{l}\text { No fiber } \\
\text { With fibers }\end{array}$ & 174 & 177 & 177 & 170 & 172 & 172 & 170 & 171 & 172 & 172 & 176 & 176 & 177 & 172 & 173 & 159 \\
& & & 170 & 165 & 163 & 163 & 169 & 166 & 166 & 169 & 173 & 173 & 168 & 172 & 163 \\
\hline $\begin{array}{l}\text { Wet density } \\
\left(\mathrm{kg} / \mathrm{m}^{3}\right)\end{array}$ & No fiber & 2000 & 2001 & 1976 & 1872 & 1873 & 1871 & 1854 & 1878 & 1879 & 1880 & 1893 & 1897 & 1902 & 1889 & 1892 & 1876 \\
& With fibers & & & 1783 & 1787 & 1776 & 1770 & 1793 & 1794 & 1798 & 1796 & 1798 & 1800 & 1811 & 1807 & 1786 \\
\hline $\begin{array}{l}\text { Dry density } \\
\left(\mathrm{kg} / \mathrm{m}^{3}\right)\end{array}$ & No fiber & 1915 & 1864 & 1835 & 1666 & 1642 & 1649 & 1632 & 1692 & 1700 & 1661 & 1631 & 1606 & 1594 & 1718 & 1729 & 1678 \\
\hline $\begin{array}{l}\text { Thermal } \\
\begin{array}{l}\text { conductivity } \\
(\mathrm{W} /(\mathrm{m} . \mathrm{K}))\end{array}\end{array}$ & With fibers & & & & 1545 & 1543 & 1551 & 1495 & 1570 & 1584 & 1572 & 1541 & 1502 & 1489 & 1603 & 1610 & 1584 \\
\hline
\end{tabular}




\subsection{Physical properties}

\subsubsection{Shrinkage}

When discussing the shrinkage of earth materials, normative documents refer only to the linear shrinkage (SNZ 4298, 1998; Walker and Australia, 2002; Lehmbau Regeln, 2009). However, as it can be seen in Figure 3, the results are quite variable between linear and volumetric shrinkage. Volumetric shrinkage seems a more sensitive parameter, with much higher values than linear shrinkage, which may not be representative of total shrinkage.

No clear linear relationship was observed between binder content and either the linear or volumetric shrinkage. However, the use of fibers was positive: in most of the cases their use reduced both the linear and the volumetric shrinkage. The only exceptions were mortars stabilized with hydraulic lime. In fact the addition of fibers to the MRE mortar does not decrease much the linear shrinkage but strongly decreases its volumetric shrinkage. The linear shrinkage of mortars increases when they are stabilized with CL and CL plus fibres increase the volumetric shrinkage, being the use of 5\% CL plus fibers the less disadvantageous. In terms of linear shrinkage the opposite occurs with the NH mortars, being the stabilization with only the binder more positive than the addition with the fibers. Nevertheless the volumetric shrinkage for HL-stabilized mortars without or with fibers is lower than similar mortars with CL and more positive for $10 \%$ HL. The linear shrinkage of mortar also increases when they are stabilized with NC, particularly without fibers, while the volumetric shrinkage increases drastically for mortars without fibers. It could not be found any literature on the subject that could support the findings and, with the tests performed, it is not possible to find justification for the behaviour of all the mortars. Nevertheless it is obvious that the type of binder applied as stabilizer is very important in terms of shrinkage, as well as the presence of fibers (only neglected for unstabilized MRE mortar and NC stabilized mortars for linear shrinkage) and the type of shrinkage (linear or volumetric). The stabilizers content between 5-15\% does not present significant variation.

The lowest value, among the mortars without stabilizer, both for linear and volumetric shrinkage, is observed on MAv. This is justified by being the mortar with the lowest percentage of clay materials 
(Figure 1), which are responsible for the shrinkage. Mortars with the addition of hemp fibers and Portland cement or hydrated air lime show the lowest linear shrinkage, while natural cement and Portland cement mortars with fibers show the lowest volumetric shrinkage. These additions stabilize the clay particles in the mortars, which have no longer a dynamic behaviour.

Linear shrinkage does not exceed $2 \%$ in any of the mortars and for the mortars with addition of cement the values are less than 1\%. Considering the regulation of New Zealand (SNZ 4298, 1998) for linear shrinkage - which considers $3 \%$ to the limit of earth mortars without additions and $1 \%$ for mortars with the addition of cement (values obtained according to Alcock test) - it can be assumed that all tested mortars have acceptable values. DIN 18947 (2013) defines, for unstabilized plastering mortars, linear shrinkage limits of $3 \%$ for mortars with fibers and $2 \%$ without fibers, measured on the prismatic samples. Although the shrinkage was only quantitatively measured on the Alcock samples, the shrinkage on the prismatic samples was also low as could be seen when those samples were demoulded.

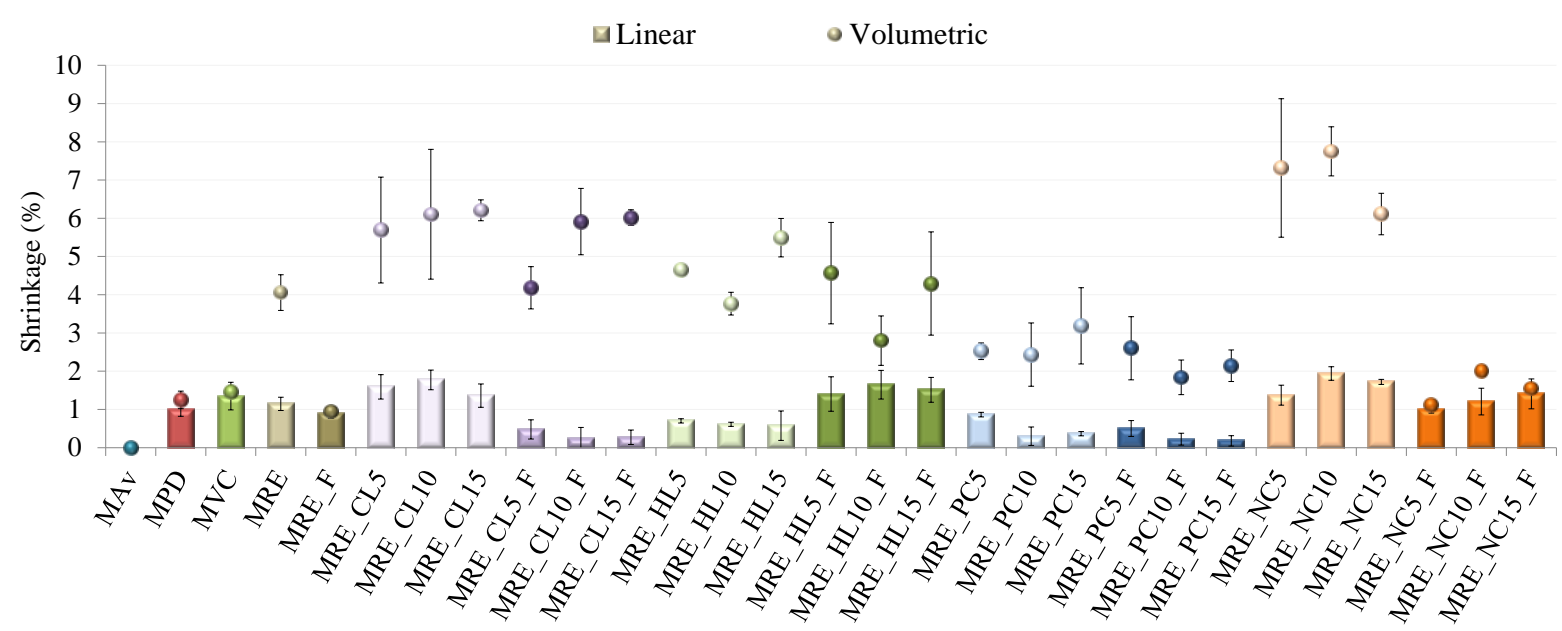

Figure 3. Linear and volumetric shrinkage of mortars at 90 days by Alcock test.

\subsubsection{Thermal conductivity and dry density}

Building materials with low thermal conductivity can be used to save heating and cooling energy. It is important to refer that the use of earth materials may allow 69\% savings of heating energy in winter and 57\% savings of cooling energy in summer (Laborel-Préneron et al., 2016). The results observed in for thermal conductivity $(\lambda)$ of the earth mortars are remarkably good (Table 4) when compared to the values obtained for cement mortars without insulation aggregates, using samples 
with the same dimensions and similar equipment (Brás et al., 2013). Indeed, the values obtained in this study for the earth mortars are similar to those found for lime mortars with volumetric proportions of 1:2 and 1:3 (air lime:sand) with four different proportions of clayish earth partially replacing an air lime or a fine sand (Faria et al., 2013).

A decrease in $\lambda$ contributes to an increase on thermal resistance proportional to the thickness of the mortar application for repairing and plastering the walls, which commonly is not very high. Nevertheless, thermal conductivity is lowest for the earth mortars with highest content of clayey material (MRE) and higher (worst) for the sandy material (MAv). Thermal conductivity reflects a tendency to decrease when fibers are added. The review done by Laborel-Préneron et al. (2016) refers several studies that corroborate this trend: an increase of fibers content leads to a decrease of thermal conductivity. Emphasis should also be drawn to the decrease of thermal conductivity when the percentage of binder is increased, with and without fibers (with the exception of the earth mortar with $10 \%$ HL). The study performed by Santos et al. (2017), with low content of air lime used to stabilize an ilitic earthen plaster, supports the same results: when a binder is added, thermal conductivity decreases. This may find justification on dry density.

The average dry density for each mortar is stated in Table 4. It can be seen that mortars with fibers systematically register lower dry densities than other mortars from the same group, corroborating results of wet density. This happens because fibers are lighter than the clayish paste and occupies volume no longer occupied by the paste. Presenting the same trend as the thermal conductivity, it can be also noted that in general mortars with higher clay content (MRE) have lower dry density, particularly when compared to those with sandy materials (MAv). This is corroborated by Walker (1995) who reports that dry densities are closely related to the clay content of the soil, generally decreasing with increasing clay content.

\subsubsection{Porosity and porosimetry}

The MIP curves obtained for different mortar samples are presented in Figure 4. The corresponding values of open porosity and main pore size are presented in Table 5. 


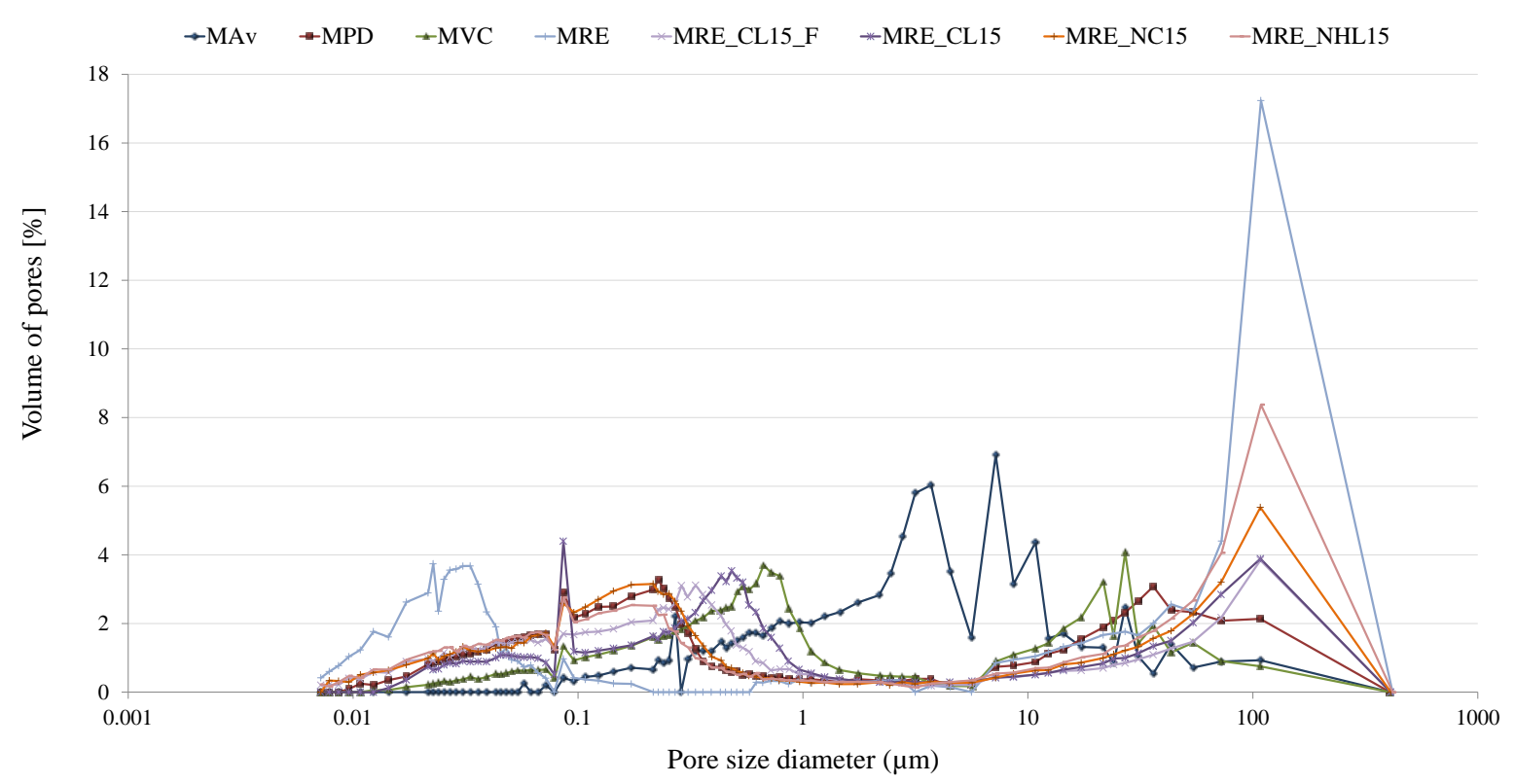

Figure 4. Mercury porosimetry curves of mortars.

Table 5

Open porosity by mercury intrusion and main pore size diameter of mortars.

\begin{tabular}{|c|c|c|c|c|c|c|c|c|c|}
\hline & \multirow[t]{2}{*}{ Mortars } & \multirow[t]{2}{*}{ MAv } & \multirow[t]{2}{*}{ MPD } & \multirow[t]{2}{*}{ MVC } & \multicolumn{5}{|l|}{ MRE } \\
\hline & & & & & - & CL15 & HL15 & PC15 & $\mathrm{NC} 15$ \\
\hline \multirow{2}{*}{$\begin{array}{l}\text { Open } \\
\text { porosity by } \\
\text { MIP }(\%)\end{array}$} & No fiber & 25.61 & 28.35 & 26.08 & 35.13 & 33.84 & 37.40 & $*$ & 32.26 \\
\hline & With fibers & - & - & - & $*$ & 38,10 & $*$ & $*$ & $*$ \\
\hline \multirow{2}{*}{$\begin{array}{l}\text { Main pore } \\
\text { size } \\
\text { diameters and } \\
\text { occurrence } \\
(\mu \mathrm{m}-\%)\end{array}$} & No fiber & $7-7$ & $\begin{array}{l}36-3 \text { and } \\
0.2-3.2\end{array}$ & $\begin{array}{l}27-4 \text { and } \\
0.7-3.8\end{array}$ & $\begin{array}{l}108-17 \text { and } \\
0.03-3.8\end{array}$ & $\begin{array}{l}108-3.8 \text { and } \\
0.5-3.5\end{array}$ & $\begin{array}{l}109-8.3 \text { and } \\
0.2-2.3\end{array}$ & $*$ & $\begin{array}{l}108-5.2 \text { and } \\
0.2-3\end{array}$ \\
\hline & With fibers & - & - & - & $*$ & $\begin{array}{l}108-3.8 \text { and } \\
0.3-3\end{array}$ & $*$ & $*$ & $*$ \\
\hline
\end{tabular}

*It was not possible to perform the test - specimens deteriorated.

The MIP open porosity is generally in agreement with the thermal conductivity. Indeed, as it would be expected, mortars with higher porosity have the lowest thermal conductivity - with the exception of MPD (Tables 4 and 5).

It is interesting to compare the mortar MRE_CL15 with and without fibers: it is observed that, as expected, fibers reduce density as well as thermal conductivity and increase porosity, while avoiding excessive dimensional variations. As a result, increasing porosity consequently presents a lower density, which led to a decrease in thermal conductivity. This statement is also corroborated by Bouguerra et al. (1998). Different results are detectable when a binder is added: comparing the mortars MRE and MRE_CL15 is possible to verify a decrease in porosity, but also in density and thermal conductivity. Lawrence et al. (2007) and Van Gerven et al. (2007) refer that carbonation 
decreases total porosity of cement mortars. This may be an explanation, although the present results refer to earth mortars with lime but with this binder - lime - carbonation also happens.

In terms of pore size and occurrence it can be observed in Figure 4 that mortars with the reference earth (MRE-based mortars) have the main pore size around 108-109 $\mu \mathrm{m}$, while the mortars with locals rammed earths have around $36 \mu \mathrm{m}, 27 \mu \mathrm{m}$ and $7 \mu \mathrm{m}$, respectively for MPD, MVC and MAv. The occurrence of the main pore diameter of $108 \mu \mathrm{m}$ is more impressive for the reference earth mortar without binder addition, with 17\%; all the other main pore diameters occurred with percentages of $8-3 \%$ to $3 \%$ for the bigger diameter or $3.8 \%$ to $2.3 \%$ when a bi-modal diameter occurred. This happened for all the mortars except for MAv (the mortar made with the earth with the lowest clay content, mixed without addition of sand), with only a peak.

\subsection{Hydric properties}

\subsubsection{Water absorption under low pressure}

Karsten tubes were used to measure the penetration of water under low pressure into the mortars. It is a general rule that a surface repair coating or a render should not only allow quick evaporation of the water that penetrates in its porous structure but also minimize that penetration when directly exposed to rainy water.

Table 6 reports the results of the Karsten water penetration test. In general, it appears that the mortars with fibers have quicker water absorption under low pressure. The reason is probably that fibers can absorb a significant amount of water because of their high absorption capacity. The mortars with fibers MRE, MRE_CL5 and MRE_CL10, the unstabilized and less strongly stabilized mortars, are the only exceptions, presenting slower water absorption under low pressure.

The slowest water absorption in unstabilized mortars are shown by MAv, MPD and MVC mortars with 2254, 2005 and 1917 s for $4 \mathrm{ml}$, respectively, while on the contrary, MRE mortars, with a kaolinitic clay, absorb water much more quickly. It means that the mortars made with the rammed earth materials, MAv, MPD and MVC, provide the best microstructure, preventing rapid water intake into the mortar matrix. These mortars present the lowest open porosity (Table 5) and they 
present also the lowest main pore size. The slowest water absorption under low pressure of these mortars may also be justified by the type of clay, which seems to play an important role in preventing rapid water penetration into the mortar (see Table 1).

When comparing the stabilized MRE mortars with their reference (MRE mortar) it can be noticed that the additions of $5 \%$ of $\mathrm{CL}$ and $\mathrm{HL}$ and $15 \%$ of HL (the latest only without fibers) and are positive in terms of water absorption under low pressure. When analysing only the stabilized mortars, it can be observed that, with the exception of three mortars, the time of water penetration by the Karsten tubes generally decreases with the increase of binder, meaning that the increase of binder is negative. That may find justification on the fact that an increase of binder, creating a stronger net between the clay particles, prevents them to swell and, therefore, to contribute to block the water ingress.

Table 6

Water absorption of mortars by Karsten tube (4 ml).

\begin{tabular}{|c|c|c|c|c|c|c|c|c|c|c|c|c|c|c|c|c|c|}
\hline & \multirow[t]{2}{*}{ Mortars } & \multirow[t]{2}{*}{ MAv } & \multirow[t]{2}{*}{ MPD } & \multirow[t]{2}{*}{ MVC } & \multicolumn{13}{|c|}{ MRE } \\
\hline & & & & & - & CL5 & CL10 & CL15 & HL5 & HL10 & HL15 & PC5 & PC10 & PC15 & NC5 & $\mathrm{NC10}$ & $\mathrm{NC} 15$ \\
\hline \multirow{2}{*}{$\begin{array}{l}\text { Time of } \\
\text { absorption (s) }\end{array}$} & No fibers & 2254 & 2005 & 1917 & 64 & 183 & 20 & 9 & 131 & 41 & 75 & 36 & 8 & 11 & 71 & 29 & 8 \\
\hline & With fibers & - & - & - & 190 & 202 & 116 & 6 & 126 & 35 & 21 & 33 & 5 & 10 & 71 & 27 & 8 \\
\hline
\end{tabular}

\subsubsection{Capillary water absorption}

Observing the capillary absorption curves shown in Figure 5, it is seen that the unstabilized mortars present nonlinear (exponential) time $e^{1 / 2}$ dependence during the first minutes, but afterwards the amount of water absorbed per unit area becomes directly proportional to the square root of elapsed time. This anomalous behaviour was probably due to clay swelling. The anomalous suction behaviour during the first minutes disappears with the addition of even the smallest amounts of binder, probably because clay swelling did not take place in these cases. This anomalous behaviour is detailed in Gomes et al. (2016a). 


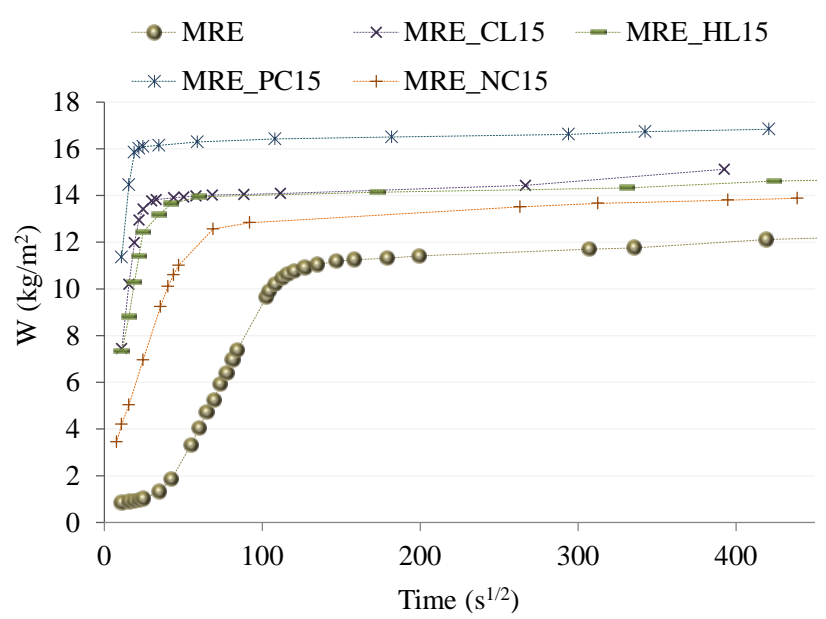

Figure 5. Absorption curve showing the anomalous capillary suction behaviour of the unstabilized mortar MRE and the capillary suction behaviour of stabilized mortars with $15 \%$ of CL, HL, PC and NC.

Capillary absorption coefficients (CC) can be seen in Table 7 and it can be concluded that:

i. mortars with local earths (MAv, MPD and MVC) have the lowest capillary absorption coefficient;

ii. the capillary absorption coefficient increases with the percentage of binder for all the four types of binders;

iii. with the addition of Portland or natural cement the fibers seems to significantly influence the results of the capillary absorption coefficient.

\section{Table 7}

Capillary absorption coefficient, maximum quantity of water adsorbed under low pressure, drying index and drying rate of the tested mortars at 90 days.

\begin{tabular}{|c|c|c|c|c|c|c|c|c|c|c|c|c|c|c|c|c|c|}
\hline & \multirow{2}{*}{ Mortars } & \multirow[t]{2}{*}{ MAv } & \multirow[t]{2}{*}{ MPD } & \multirow[t]{2}{*}{ MVC } & \multicolumn{13}{|c|}{ MRE MRE } \\
\hline & & & & & - & CL5 & CL10 & CL15 & HL5 & HL10 & HL15 & PC5 & PC10 & PC15 & NC5 & $\mathrm{NC10}$ & $\mathrm{NC} 15$ \\
\hline \multirow{2}{*}{$\begin{array}{l}\mathrm{CC} \\
\left(\mathrm{kg} /\left(\mathrm{m}^{2} \cdot \mathrm{s}^{1 / 2}\right)\right)\end{array}$} & & .04 & 0.03 & 0.05 & 0.14 & 3 & 0.47 & 0.51 & 10 & 12 & 0.38 & 0.26 & 45 & 0.57 & 0.06 & 0.15 & 0.21 \\
\hline & With fibers & & & & 0.23 & 0.21 & 0.34 & 0.47 & 0.05 & 0.11 & 0.26 & 0.33 & 0.51 & 0.68 & 0.10 & 0.24 & 0.40 \\
\hline \multirow{2}{*}{$\mathrm{W}\left(\mathrm{kg} / \mathrm{m}^{2}\right)$} & No fibers & 8.61 & 8.42 & 9.77 & 11.46 & 13.93 & 14.30 & 14.19 & 11.73 & 11.75 & 13.92 & 14.44 & 15.78 & 16.71 & 11.78 & 12.44 & 13.29 \\
\hline & With fibers & & & & 12.99 & 14.24 & 14.11 & 14.57 & 13.14 & 13.32 & 13.94 & 15.29 & 16.09 & 16.71 & 13.60 & 12.91 & 12.03 \\
\hline \multirow{2}{*}{$\begin{array}{l}\text { Drying índex } \\
(-)\end{array}$} & 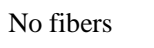 & 0.23 & 0.14 & 0.14 & 0.12 & 0.1 & 0.16 & 0.15 & 0.12 & 0.13 & 0.13 & 0.15 & 0.18 & 0.18 & 0.12 & 0.13 & 0.14 \\
\hline & With fibers & & & & 0.13 & 0.15 & 0.17 & 0.18 & 0.13 & 0.15 & 0.16 & 0.15 & 0.18 & 0.19 & 0.14 & 0.15 & 0.15 \\
\hline \multirow{2}{*}{$\begin{array}{l}\text { Drying rate } \\
\left(\mathrm{kg} /\left(\mathrm{m}^{2} \cdot \mathrm{h}\right)\right)\end{array}$} & No fibers & .08 & 0.11 & 0.11 & 0.13 & 0.14 & 0.14 & 0.13 & 0.19 & 0.13 & 0.14 & 0.12 & 0.12 & 0.13 & 0.14 & 0.14 & 0.15 \\
\hline & With fibers & & & & 0.13 & 0.14 & 0.12 & 0.13 & 0.13 & 0.15 & 0.14 & 0.13 & 0.13 & 0.13 & 0.13 & 0.14 & 0.15 \\
\hline
\end{tabular}

CC - Capillary absorption coefficient;

W - Water absorbed per unit area.

Analysing the capillary absorption coefficient of the MRE mortar with $15 \%$ of hydrated air lime $\left(0.51 \mathrm{~kg} /\left(\mathrm{m}^{2} \cdot \mathrm{s}^{1 / 2}\right)\right)$ in Table 7 , similar values were found in a study presented by Faria (2016); a value of $0.48 \mathrm{~kg} /\left(\mathrm{m}^{2} . \mathrm{s}^{1 / 2}\right)$ was observed for capillary absorption coefficient for lime-earth mortars with a proportion in volume of 1:3 (lime:sand) with a mass replacement ratio of $25 \%$ of air lime by earth. 
Observing the results for stabilized mortars on Table 6, there is a trend of decreasing the time of water penetration under low pressure with the increase of stabilizer. Comparing with the results for stabilized mortars on Table 7, there is also a trend to increase the amount of water absorbed by capillary with the increase of stabilizer. This explanation holds up to the fact that, for the water absorption by capillary, the thinner the pores (within the capillary range), the greater the capillary rise will be. Contrasting for the water absorption test by gravity, the water pressure will be superior and a microstructure with large pores will have a higher absorption. This can be observed in the MRE mortars: as the porosity increases (Table 5), the absorption time under low pressure also increases (Table 6).

Observing the average values of the water absorbed by capillary per unit area (W) for the tested mortars in Table 7, it can be seen that:

iv. the highest amount of absorbed water is recorded in mortars with addition of Portland cement;

ii. when the percentage of stabilizer increases there is a general tendency to increase the amount of absorbed water;

iii. in general the introduction of fibers increases the amount of absorbed water;

iv. when comparing the unstabilized mortars, it appears that MRE reaches a highest amount of absorbed water, in comparison with MAv, MPD and MVC. This should be due to the higher percentage of clay of the MRE dry mix (Figure 2). It can also be justified by the mineralogical characteristics of the clay (Table 1) because RE has less swelling clays than the other earths $\mathrm{Av}, \mathrm{PD}$ and $\mathrm{VC}$ - and can, therefore provide a lower blockage to water ingress;

v. stabilized mortars can significantly increase the amount of water absorbed when compared with unstabilized MRE mortars, which is an undesirable effect. The reason is that the addition of binder increases the open porosity of the mortar, as seen in Table 5 and discussed in detail elsewhere (Gomes et al., 2016a);

vi. comparing the unstabilized mortars MAv, MPD and MVC, it is found that: 
- MPD reaches a smaller amount of absorbed water, despite of presenting a higher percentage of clay (Figure 2); but as seen in Table 1 it is a non-swelling clay.

- MVC presents a greater amount of absorbed water but a lower percentage of clay (Figure 2). However, in its mineral composition it presents a most expansive clay - chlorite (Table 1) - in a higher proportion when compared with the others rammed earth materials Av and PD. Therefore the amount of absorbed water depends on the content and type of clay in the mortars formulation.

\subsubsection{Drying}

It is required that mortars facilitate drying, i.e., release moisture from a building that was introduced during application of the mortars, as well as the moisture that may subsequently be absorbed by the mortars (rain water, capillary rise) or humidity produced inside the building. Thus, it is preferable that mortars show high drying rate, in order to ensure higher initial drying, and low drying index, indicating an easy global drying.

The drying behaviour of the mortars was evaluated by their evaporation curve. In this test, the initial water content influences the results because the amount of water to be released will be different. Nevertheless, the drying rate refers to the first drying stage, when the liquid phase is continuous in the network of pores and the evaporation front is located at the surface of the material. This rate corresponds to the slope of the initial portion of the drying curve versus time.

Analysing the drying rate and the drying index it can be concluded that (Table 7 and Figure 6):

i. fiber additions retard drying:

- they affect the initial rate of drying, giving rise to lower values of the stage I drying rate;

- mortars with fibers present higher drying index (MRE_PC10 is the only exception); this happens probably because the fibers release moisture more slowly than the other mortar constituents;

ii. binders also seem to hamper drying; in general, drying becomes slower as the binder content increases; 
iii. taking into account the drying index for mortars with the additions of binders, the slower drying occur in mortars with Portland cement, with and without fibers, followed by mortars with hydrated air-lime mortars with and without fibers;

iv. analysing the drying index the faster drying is recorded in the mortars with: hydraulic lime without fibers; natural cement without fibers; and in the reference-earth mortar with and without fibers.

It was observed that mortars with hemp fibers absorb higher amounts of water and takes more time to release that moisture when compared with the same mortars without fibers. A study made by Arizzi et al. (2015) refer that samples with hemp lime composites absorbed a much greater amount of water when compared to a reference mortar made with air lime and stone aggregate. Conversely, in drying properties that study shows that hemp lime composite did not slow down the drying rate.

MAv mortar has the lowest drying rate, opposed to MRE_HL5 that has the highest (Figure 6). MAv mortar also has the highest drying index. That shows that a fast initial drying does not assure a fast total drying. Nevertheless, the mortar that has the highest drying rate also has the lowest drying index, MRE_HL5. It is also important to note that the remainder group, with natural hydraulic lime without the addition of fibers, had the highest values for the drying rate and the lowest values for the drying index. 


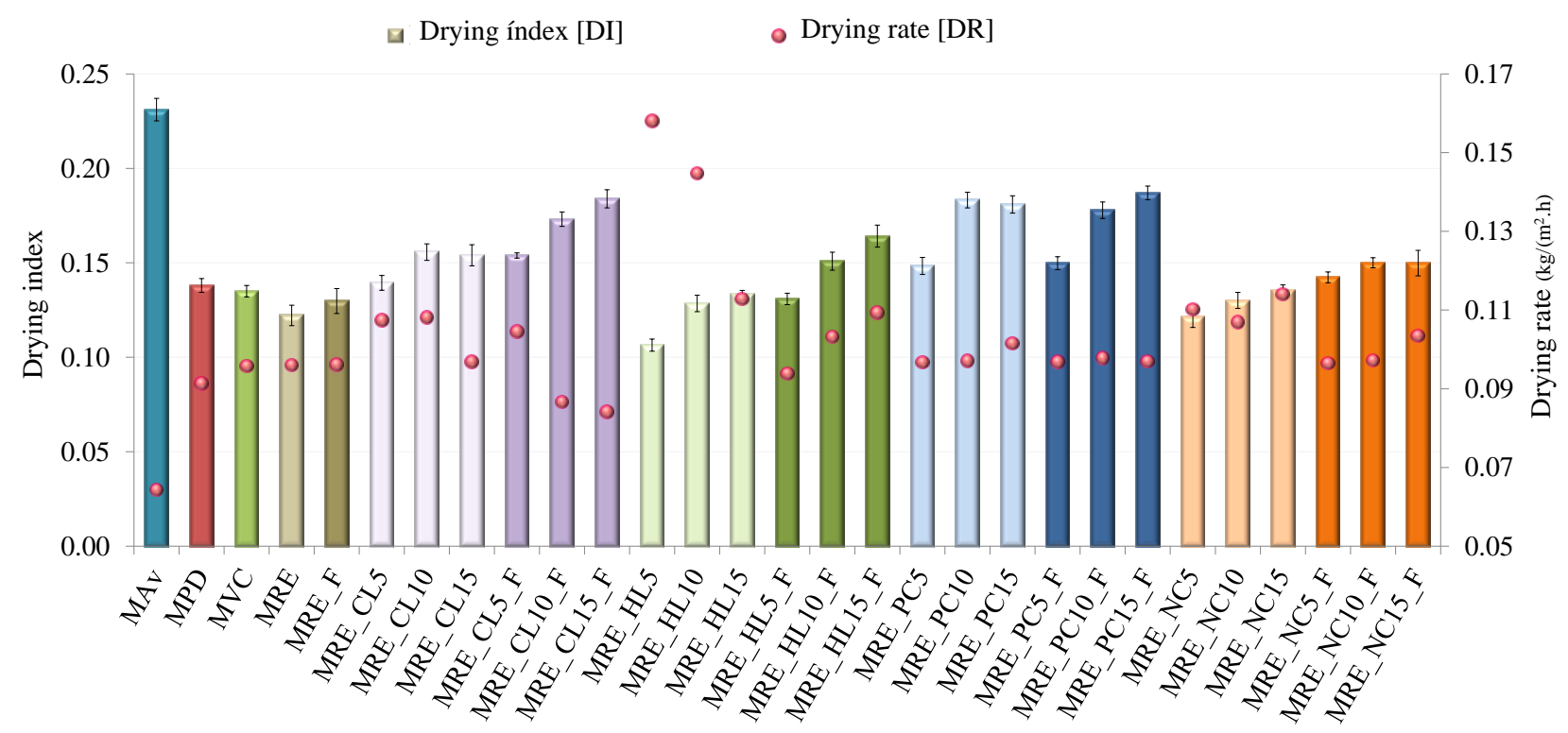

Figure 6. Drying index and drying rate on the $1^{\text {st }}$ phase of tested mortars at 90 days.

During the hydric tests, strong microbial growth was observed in all mortars, caused by hemp fibers. The highest amount of fungi appeared in the mortars with the lowest binder content, decreasing with increasing binder content. It thus appears that even in mortars which include a binder with fungicidal properties, as is the case of hydrated air lime, natural fibers enhance the growth of mould/fungi. This was also stated by Santos et al. (2017), where the addition of $5 \%$ of air lime to an earthen plaster with oat fibers strongly decreased but not completely prevented fungal development. Therefore microorganisms induced serious aesthetic damage under wet-dry conditions. The presence of mould/fungi may discourage the use of hemp fibers in earth construction; consequently preventive measures should be taken to reduce the proliferation of mould/fungi as, for example, improve ventilation.

\subsection{Mechanical properties}

Mortars for general repair, rendering or plastering of walls should have similar characteristics physical, mechanical and chemical - to the walls where they are to be applied, in order to really protect them (Delinière et al., 2014) but also to be as durable as possible without jeopardizing the first condition. However this normally is not secured (Gomes et al., 2012a); frequently too strong mortars are applied on earthen walls, as the case of cement-based mortars. The main problem is to 
ensure long-term compatibility between the mortar and the support, which the mortar was supposed to protect.

Table 8 presents the results of the dynamic elasticity modulus, flexural and compressive strength of the mortars at 90 days. Some are so low that some microcracking may have occurred. The flexural and compressive strength of the unstabilized mortars (only with material collected from buildings MAv, MPD, MVC - and the reference earth - MRE), achieved much higher values when compared with the stabilized mortars. Analysing the results only for unstabilized mortars, MRE achieved lower flexural and compressive strength when compared with the other unstabilized mortars. This behaviour may occur because of the mineralogical composition of the fine fraction - clay particles. The high specific surface and the lamellar form of the clay particles allow, for a given water content, to form a water film between the lamellae, which will connect them together by capillary forces, i.e. the higher the specific surface, the greater the strength. Analysing the clays with the highest specific surface (Table 1), it is verified that: chlorite presents the highest specific surface and is only present in the VC material in low proportion; illite also presents a high specific surface although lower than chlorite - and appears in intermediate proportion in the VC material followed by PD; the clay with lowest specific surface is the kaolinite, being present in intermediate proportion in the RE material followed by PD and by VC and Av. Therefore the presence of clayish fines with the lowest specific surface in RE material may justify the lower strengths of MRE mortar.

The same trend is observed for the dynamic modulus of elasticity; the highest modulus (lower deformability) was verified for the local earths; the mortars MRE unstabilized also achieved a high value. Generally, as the percentage of stabilizer increases, the dynamic modulus of elasticity decreases (with and without fibers). Nevertheless this effect was not observed for mortars stabilized with hydrated air lime.

The results of flexural and compressive strength show that there is no clear relationship with the percentage of binder, contrary to what would be expected. This might be due to the low percentages of binder added that did not produced chemical reactions, as has been shown by Santos et al. (2017) 
with a kaolinitic earth plaster stabilized with $5 \%$ of air lime, or not strong enough chemical reactions (by carbonation and hydration) that could compensate the discontinuity created by the binder particles between the lamellar clay particles, strongly reducing their bond and the inherent mortar strength. For the same percentage of binder, the mortars with natural cement have the highest flexural and compressive strength.

In general, for the same binder content, the introduction of fibers increases the flexural and compressive strength. However, it did not have a significant impact on the dynamic modulus of elasticity.

Minke and Ziegert (2008) cites the German standard (Lehmbau Regeln, 2009) which states that earth mortars must have a compressive strength greater than $0.5 \mathrm{MPa}$ when applied on secondary spaces, for mortars tested according to the EN 1015-11 (2006). Comparing this value with the results obtained for the studied mortars (Table 8), only 8 (MAv, MPD, MVC, MRE, MRE_F and the MRE_NC_F group) out of 29 mortars achieve this threshold. Nevertheless more mortars accomplish the EN 998-1 (2016) requirements for mortars, defined at $0.4 \mathrm{MPa}$ for minimal compressive strength.

Rammed earth presents a relatively weak surface, unable to withstand rigid mortars. Rammed earth walls can present compressive strength of 0.50 to $4.00 \mathrm{MPa}$ according to Walker et al. (2005), 1.30 MPa according to New Zealand standard (SNZ 4298, 1998) and 1.26 MPa in experimental studies done by Silva et al. (2013a). All the studied unstabilized mortars (MAv, MPD, MVC and MRE) present a value higher than $0.5 \mathrm{MPa}$ for compressive strength; the remaining mortars, with the exception of the additions of natural cement with fibers, air lime with $15 \%$ and hydraulic lime with $5 \%$ with fibers, presents much lower values.

Mortars with low mechanical properties and consequently low modulus of elasticity can be required for very weak substrates, such as some earth walls (RILEM, 2008). According to values reported by Walker et al. (2005) that refer to a modulus of elasticity (static) for rammed earth with a range of 
100-1000 MPa and the Australian guide with values of $500 \mathrm{MPa}$ (Walker and Australia, 2002), the studied mortars present a low modulus of elasticity (Table 8) compatible with rammed earth walls.

\section{Table 8}

Dynamic modulus of elasticity, flexural strength and compressive strength of mortars at 90 days.

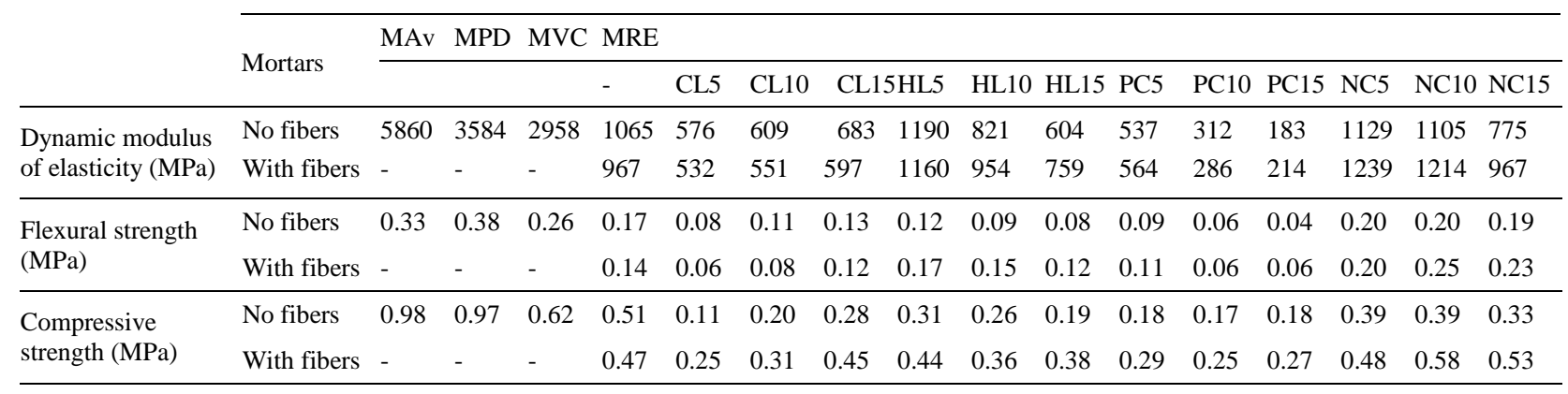

Flexural strength is more important for surface repair mortars than compressive strength. Nevertheless Figure 7 shows almost perfect concordance between the flexural and compressive strength $\left(\mathrm{R}^{2}=0.8495\right)$. When correlating flexural and compressive strength with dynamic modulus of elasticity is verified that: (i) there is a good correlation between compressive strength and modulus of elasticity $\left(\mathrm{R}^{2}=0.7645\right)$, as it is usually referred (Silva et al., 2013b; SNZ 4297, 1998); (ii) there is a coefficient of determination slightly lower $\left(\mathrm{R}^{2}=0.672\right)$ between flexural strength and modulus of elasticity.

It is also important to refer that the rupture was achieved earlier than the time required by the standard (defined to be in the range 30-90 seconds) for both flexural and compressive strength. This shows that: the standard and the test procedure used is not appropriate for earth mortars; it is necessary to have some reservations in the results observed - this may explain why, despite the clear relation with the modulus of elasticity, no relation was found between the percentage of binder and the mechanical properties as flexural and compressive strength.

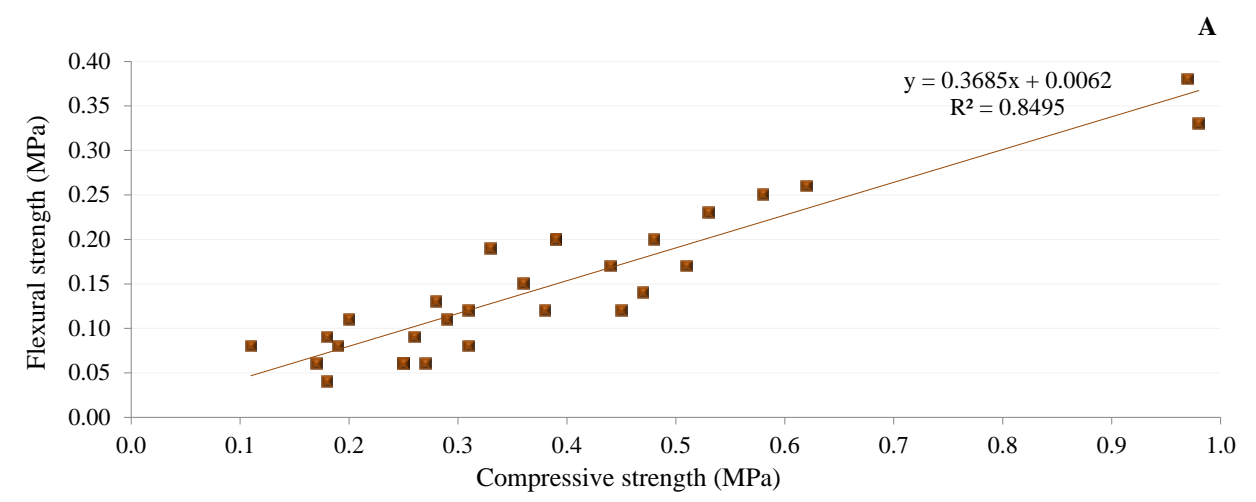




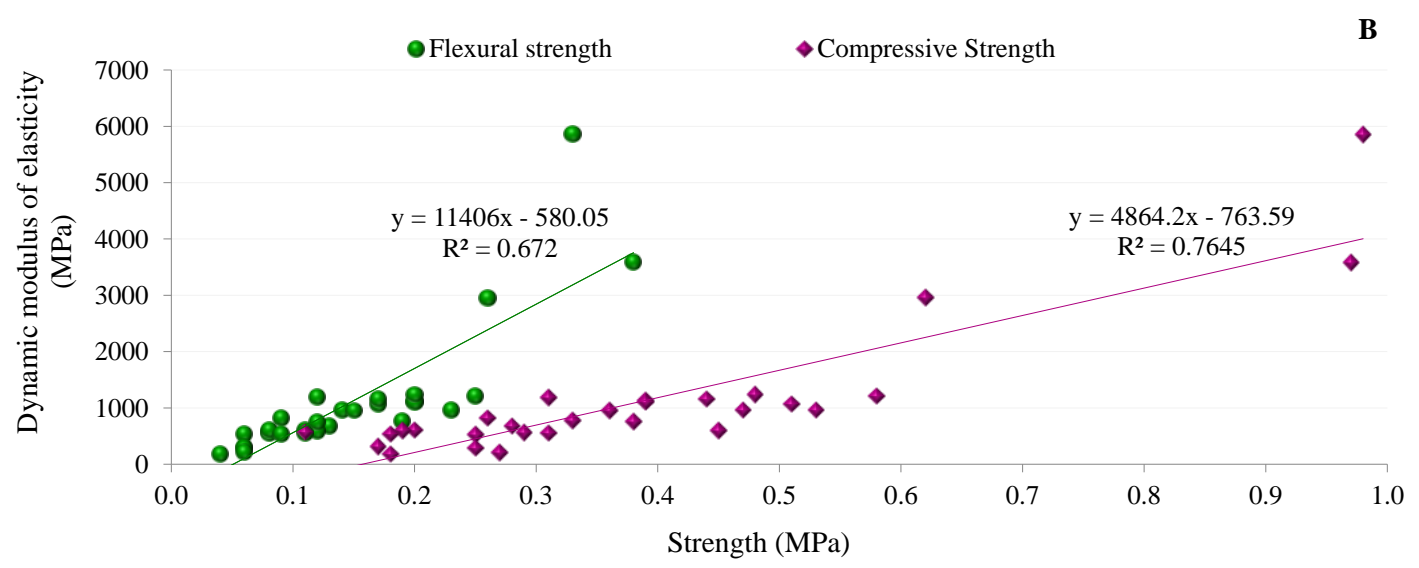

Figure 7. (A) Compressive vs flexural strength, (B) compressive and flexural strength vs dynamic modulus of elasticity.

\section{Conclusions}

The study herewith described intends to be a contribution to a better knowledge of the properties and behaviour of earth mortars, in order to help producers to optimize earth-based mortars for rammed earth repair and protection, and stakeholders to choose eco-efficient compatible mortars for interventions on that type of architecture.

It is important to remember that the use of earth as a material construction presents many advantages in a context of sustainable development; the principal is the low-environmental impact in the field. However, the characteristics like non-toxic, ecological, reusable, recyclable (when unstabilized) and locally available are also determinant. The use of building materials that, during the production process, their whole service life and their end-of-life, presents reduced consumption and pollution it is important to sustainability.

The study is based on the testing of mortars made with four different types of earth: one commercial and three recovered from rammed earth walls. The mortars made with the commercial earth were also tested after addition of natural hemp fibers and stabilization with four alternative kinds of mineral binders.

The addition of a mineral binder impacts the mortar properties in different ways. The dynamic modulus of elasticity decreases as the percentage of binder increases, which means that the binder improves the deformability of the mortars. This effect was not observed only for the mortars stabilized with hydrated air lime (with and without fibers). This is positive because the basic requirements for earth mortars when applied on unstabilized earth buildings consists into a low 
modulus of elasticity in order to minimize cracking of the support. The lower values are generally found in mortars with the addition of Portland cement binder, although in the literature hydrated air lime is always presented as having the advantage of being more deformable (lower value for dynamic modulus of elasticity). Therefore, some microcracking may have occurred in some mortar samples. It was also observed that when a binder is added, thermal conductivity decreases, which is positive because building materials with low thermal conductivity can contribute for saving heating and cooling energy.

Contrary to what would be expected there is no clear relationship with the percentage of binder to the results observed in flexural and compressive strength. This might be due to the low percentages of binder added.

However, the binders worsened other mortar properties. Increasing binder content resulted in higher water absorption and slower drying, which is undesirable because mortars must present a diminutive absorption and should facilitate drying. Note that the worst hydric behaviour (higher water absorption coefficient, lowest Karsten water penetration time and longest drying time) was observed with the addition of Portland cement. The stabilization with any of the four tested binders enabled linear time ${ }^{1 / 2}$ dependence, probably because the swelling did not take place in this case this feature was inhibited. However, the stabilizers also significantly increase the capillary suction and the capillary porosity, in comparison with the unstabilized mortars, which suggests that the use of stabilizers may lead to an intensification of moisture-related anomalies in earth constructions.

The addition of hemp fibers (5\% of the mass of earth) had better effects but still presented relevant limitations. The fibers decreased the drying shrinkage of the mortars, meaning that with no volume decrease, no internal stresses are generated and, as a consequence, cracking decreases; this is highly beneficial for a repair mortar or a render. Note that this conclusion was based on evaluating not only the linear shrinkage, as it is usual, but also the volumetric shrinkage. Indeed, the linear shrinkage test is not enough to evaluate this property because do not identify the real shrinkage of the mortar; therefore it is advisable to consider also the volumetric shrinkage for this type of mortars. 
Other positive effects of the addition of hemp fibers were the reduction of density as well as thermal conductivity and increase of porosity and flexural and compressive strengths, while avoiding excessive dimensional variations. The incorporation of fibers reduces the propagation of cracks through the good adherence of fibers to the clay matrix and, therefore, improves their mechanical properties. However, the addition of fibers results in slower drying of the mortars - this aspect can turn out to be negative for the long-term durability of the building. A possible explanation is that the natural hemp fibers release moisture more slowly than the other mortar constituents. The use of hemp fibers also represents another problem in earth building, which is the microbial growth, which needs to be reduced by taking the necessary preventive measures as ventilation.

\section{Acknowledgements}

Authors are grateful to the people who collaborated in the experimental work, in particular LNEC researcher António Santos Silva and technicians José Costa, João Junior, Luís Nunes and Bento Sabala and from Nova University of Lisbon the Engineer Vitor Silva. The researchers thank George Hilbert for providing the natural cement within the ROCARE EU project. Thanks are due to the companies Sorgila, Lusical and Secil for providing the remaining materials. The work is within RILEM Technical Committee TCE - Testing and Characterisation of Earth-based building materials and elements and project PTDC/EPH-PAT/4684/2014: DB-HERITAGE - Data base of building materials with architectural heritage and historic importance.

\section{References}

Arizzi, A., Brümmer, M., Martín-Sanchez, I., Cultrone, G., Viles, H., 2015. The influence of the type of lime on the hygric behaviour and bio-receptivity of hemp lime composites used for rendering applications in sustainable new construction and repair works. PLoS ONE., 10(5), e0125520.

Ashurst, J., Ashurst, N., 1995. Pratical Building Conservation: Brick, Terracotta \& Earth, Volume 2. English Heritage Technical Handbook. Gower technical press, Hampshire, England.

Bouguerra, A., Ledhem, A., de Barquin, F., Dheilly, R.M., Quéneudec, M., 1998. Effect of microstructure on the mechanical and thermal properties of lightweight concrete prepared from clay, cement, and wood aggregates. Cement Concrete Res., 28(8), pp.1179-1190. 
Boussalh, M., Jlok, M., Guillaud, H., Moiset, S., 2004. Manuel de Conservation du Patrimoine Architectural en Terre des Vallés Présahariennes du Maroc, CERKAS-Centre du Patrimoine Mondial de 1'UNESCOCRATerre - Centre de Recherché et d'Application.

Brás, A., Leal, M., Faria, P., 2013. Cement-cork mortars for thermal bridges correction. Comparison with cement-EPS mortars performance. Constr. Build. Mater., 49, pp.315-27.

Darling, E.K., Cros, C.J., Wargocki, P., Kolarik, J., Morrison, G.C., Corsi, R.L., 2012. Impacts of a clay plaster on indoor air quality assessed using chemical and sensory measurements. Build. Environ., 57, pp. 370-376.

Delinière, R., Aubert, J.E., Rojat, F., Gasc-Barbier, M., 2014. Physical, mineralogical and mechanical characterization of ready-mixed clay plaster. Build. Environ., 80, pp.11-17.

DIN 18946, 2013. Earth Masonry Mortar: Terms and Definitions, Requirements, Test Methods (in German). German Institute for Standardization. Berlin.

DIN 18947, 2013. Earth Plasters: Terms and Definitions, Requirements, Test Methods (in German). German Institute for Standardization. Berlin.

E196, 1966. Particle Size Analysis (by Dry Sieving and Sedimentation) (in Portuguese). LNEC (National laboratory for Civil Engineering), Lisbon.

E239, 1970. Particle Size Analysis by Wet Sieving (in Portuguese). LNEC (National laboratory for Civil Engineering), Lisbon.

EN 196-1, 2016. Methods of Testing Cement - Part 1: Determination of Strength). European Committee for Standardization (CEN), Brussels.

EN 197-1, 2011. Cement. Part 1: Composition, Specifications and Conformity Criteria for Common Cements. European Committee for Standardization (CEN), Brussels.

EN 459-1, 2015. Building Lime. Part 1: Definitions, Specifications and Conformity Criteria. European Committee for Standardization (CEN), Brussels.

EN 998-1, 2016. Specification for Mortar for Masonry. Part 1: Rendering and plastering mortar. European Committee for Standardization (CEN), Brussels.

EN 1015-3, 1999. Methods of Test for Mortar for Masonry. Part 3: Determination of consistence of fresh mortar (by flow table). European Committee for Standardization (CEN), Brussels.

EN 1015-6, 1998. Methods of Test for Mortar for Masonry. Part 6: Determination of Bulk Density of Fresh Mortar. European Committee for Standardization (CEN), Brussels. 
EN 1015-10, 1999. Methods of Test for Mortar for Masonry. Part 10: Determination of Dry Bulk Density Harden Mortar for Masonry. European Committee for Standardization (CEN), Brussels. A1:2006.

EN 1015-11, 2006. Methods of Test for Mortar for Masonry. Part 11: Determination of Flexural and Compressive Strength of Hardened Mortar. European Committee for Standardization (CEN), Brussels.

EN 14146, 2004. Natural Stone Test Methods. Determination of the Dynamic Modulus of Elasticity (by measuring the fundamental resonance frequency). European Committee for Standardization (CEN), Brussels.

EN 15801, 2009. Conservation of Cultural Property. Test methods: Determination of Water Absorption by Capillarity. European Committee for Standardization (CEN), Brussels.

EN 16302, 2013. Conservation of Cultural Heritage. Test Methods - Measurement of Water Absorption by Pipe Method. European Committee for Standardization (CEN), Brussels.

EN 16322, 2013. Conservation of Cultural Heritage. Test Methods: Determination of Drying Properties. European Committee for Standardization (CEN), Brussels.

Faria, P. 2016. Earth and lime mortars - characteristics and applications (in Portuguese). A Cal no Espaço Ibérico: Um Futuro com História, in: Veiga, R., Menezes, M., Santos Silva, A., Santos, A.R., Santos, D., Botas. S. (Eds.), V FICAL - Jornadas do Fórum Ibérico da Cal, LNEC, pp.277-286.

Faria, P., Silva, V., Jamú, N., Dias, I., Gomes, M. I., 2013. Evaluation of air lime and clayish earth mortars for earthen wall renders, in: Correia, M., Carlos, G., Rocha, S. (Eds), Vernacular Heritage and Earthen Architecture. Contributions for Sustainable Development. CRC Press / Taylor \& Francis Group, pp. 407413.

Faria, P., Santos, T., Silva, V., 2014. Earth-based mortars for masonry plastering, in: Lourenço, P., Haseltine, B., Vasconcelos, G. (Eds.), Proceeding of International Masonry Society. $9^{\text {th }}$ International Masonry Conference, Guimarães, Portugal.

Gomes, M.I., Gonçalves, T.D., Faria, P., 2016a. Hydric behavior of earth materials and the effects of their stabilization with cement or lime: study on repair mortars for historical rammed earth structures. J. Mater. Civil. Eng., 28(7), 04016041.

Gomes, M.I., Gonçalves, T.D., Faria, P., 2016b. Characterization of earth-based mortars for rammed earth repair, in: Feiglstorfer, H. (Eds.), Earth Constructions \& Tradition. IVA-ICRA. Institute for comparative research in architecture, Viena, Austria, pp. 257-273.

Gomes, M.I., Gonçalves, T.D., Faria, P., 2014. Unstabilised rammed earth: characterization of the material collected from old constructions in south Portugal and comparison to normative requirements. Int. J. Archit. Herit., 8(2), pp.185-212. 
Gomes, M.I., Gonçalves, T.D., Faria, P., 2013. The compatibility of earth-based repair mortars with rammed earth substrates, in: Hughes, J. (Eds.). $3^{\text {rd }}$ Historic Mortars Conference, Glasgow, Scotland.

Gomes, M.I., Gonçalves, T.D., Faria, P., 2012a. Earth-based repair mortars : experimental analysis with different binders and natural fibers, in: Mileto, C., Vegas, F., Cristini, V. (Eds.), Rammed Earth Conservation: Proceedings of the first International Conference on Rammed Earth Conservation. CRC Press/Balkema, pp. 661-668.

Gomes, M.I., Gonçalves, T.D., Faria, P., 2012b. Influence of water content evaluation on the workability of an earth mortar (in Spanish). J. Cultural Heritage Studies, 25(2), pp.258-277.

Guelberth, C.R., Chiras, D., 2003. The Natural Plaster Book: Earth, Lime and Gypsum Renders for Natural Homes, New Society Publishers, Gabriola Island, Canada.

Guillaud, H., 2008. Characterization of earthen materials, in: Avrami, E., Guillaud, H., Hardy, M. (Eds.), Terra Literature Review - An overview of research in earthen architecture conservation. The Getty Conservation Institute, Los Angeles, United States, pp. 21-31.

Gustavsson, L., Joelsson, A., 2010. Life cycle primary energy analysis of residential buildings. Energ. Buildings, 42, pp.210-220.

Houben, H., Guillaud, H., 2006. Earth Construction: A Comprehensive Guide, first ed. Technology Intermediate Publications, ITDG Publishing, London.

Jiménez Delgado, M.C., Guerrero, I.C., 2006. Earth building in Spain. Constr. Build. Mater., 20(9), pp.679690.

Jiménez Delgado, M.C., Guerrero, I.C., 2007. The selection of soils for unstabilised earth building: a normative review. Constr. Build. Mater., 21(2), pp.237-251.

Keable, J., 1996. Rammed Earth Structure: A Code of Practice. Intermediate Technology Publications Ltd, London.

Keefe, L., 2005. Earth Building: Methods and Materials, Repair and Conservation. Taylor and Fancis Group, United States of America and Canada.

Laborel-Préneron, A., Aubert, J.E., Magniont, C., Tribout, C., Bertron, A., 2016. Plant aggregates and fibers in earth construction materials: a review. Constr. Build. Mater., 111, pp.719-734.

Laborel-Préneron, A., Magniont, C., Aubert, J.E., 2017. Characterization of barley straw, hemp shiv and corn cob as resources for bioaggregate based building materials. Waste Biomass Valori. https://doi.org/10.1007/s12649-017-9895-z 
Lawrence, R.M., Mays, T.J., Rigby, S.P., Walker, P., D'Ayala D., 2007. Effects of carbonation on the pore structure of non-hydraulic lime mortars. Cement Concrete Res., 37, pp.1059-1069.

Lehmbau Regeln, 2009. Terms, Materials, Components (in German). Begriffe, Baustoffe, Bauteile 3. überarb. Volhard, F., Röhlen, U. (Eds.). Dachverband Lehm e.V. (Hrsg.),Wiesbaden, Germany.

Lima, J., Faria, P., 2016. Eco-efficient earthen plasters: the influence of the addition of natural fibers. Natural Fibres: Advances in Science and Technology Towards Industrial Applications. Springer, RILEM Book Series, 12, pp.315-327.

Lima, J., Faria, P., Santos Silva, A., 2016. Earthen plasters based on illitic soils from Barrocal region of Algarve: contributions for building performance and sustainability. Key Eng. Mater., 678, pp.64-77.

Liuzzi, S., Hall, M.R., Stefanizzi, P., Casey, S.P., 2013. Hygrothermal behaviour and relative humidity buffering of unfired and hydrated lime-stabilised clay composites in a Mediterranean climate. Build. Environ., 61, pp.82-92.

Maddison, M., Mauring, T., Kirsimäe, K., Mander, U., 2009. The humidity buffer capacity of clay - sand plaster filled with phytomass from treatment wetlands. Build. Environ., 44 (9), pp.1864-1868.

Melià, P., Ruggieri, G., Sabbadini, S., Dotelli, G., 2014. Environmental impacts of natural and conventional building materials: a case study on earth plasters. J. Clean. Prod., 80, pp.179-186.

McHenry, P., 1984. Adobe and rammed earth buildings: design and construction. The University of Arizona Press. Wiley-Interscience, Arizona

Minke, G., 2006. Building With Earth - Design and technology of a Sustainable Architecture. Birkhäuser Publishers for Architecture.

Minke, G., Ziegert, C., 2008. DVL technical information sheet "The requirements of clay plasters." Dachverband Lehm e.V., In $5^{\text {th }}$ International Conference on Building with Earth, LEHM 2008. Koblenz, Germany, pp. 23-31.

New Mexico Code, 2006. New México Earthen Building Materials Code 14.7.4, New Mexico: Santa Fé, NM: Construction Industries Division (CID) of the Regulation and Licensing Department.

RILEM, 2008. Rilem TC 203-RHM: Repair mortars for historic masonry. Testing of hardened mortars, a process of questioning and interpreting. Mater. Struct., 42(7), pp.853-865.

ROCARE EU-Project, 2012. Manual on best practice in the application of roman cements, in: Gurtner, C., Hilbert, G., Hughes, D., Kozlowski, R., Weber, J. (Eds), EU-Project version 1, no. 226898. Available at: http://www.rocare.eu/page/start.html. 
Santos, T., Nunes, L., Faria, P., 2017. Production of eco-efficient earth-based plasters: influence of composition on physical performance and bio-susceptibility. J. Clean. Prod., 167, pp.55-67.

SAZS 724, 2001. Standards Association Zimbabwe. Standard Code of Practice for Rammed Earth Structures, Harare: Standards Association of Zimbabwe.

Schroeder, H., Ziegert, C., 2008. Testing the adhesive strength of clay plasters. Dachverband Lehm e.V., In $5^{\text {th }}$ International Conference on Building with Earth, LEHM 2008. Koblenz, Germany, pp. 203-205.

Silva, R., Oliveira, D., Lourenço, P., Schueremans, L., Miranda, T., 2013a. Experimental investigation on the repair of rammed earth by means of injection of mud grouts, in: Correia, M., Carlos, G., Rocha, S. (Eds.), Vernacular Heritage and Earthen Architecture: Contributions for Sustainable Development. CRC Press/Taylor \& Francis Group, London, pp. 727-733.

Silva, R., Oliveira, D., Miranda, T., Cristelo, N., Escobar, M.C., Soares, E., 2013b. Rammed earth construction with granitic residual soils: the case study of northern Portugal. Constr. Build. Mater., 47, pp.181-191.

Smith, P.F., 2005. Architecture in a Climate of Change: a Guide to Sustainable Design, second ed. Architectural Press an imprint of Elsevier, Oxford.

SNZ 4297, 1998. Engineering Design of Earth Buildings. Standards New Zealand.

SNZ 4298, 1998. Materials and Workmanship for Earth Buildings. Standards New Zealand.

UNEP SBCI, 2009. Buildings and Climate Change - Summary for Decision Makers. United Nations Environment Programme - Sustainable Buildings \& Climate Initiative.

UN, 1992. Agenda 21 - Rio Declaration. United Nations Conference on Environment \& Development, Rio de Janeiro.

Van Gerven, T., Cornelis, G., Vandoren, E., Vandecasteele, C., 2007. Effects of carbonation and leaching on porosity in cement-bound waste. Waste Manage., 27(7), pp.977-985.

Velde, B., 2008. Clay minerals, in: Avrami, E., Guillaud, H., Hardy, M. (Eds.), Terra Literature Review - An overview of research in earthen architecture conservation. The Getty Conservation Institute, Los Angeles, United States, pp. 1-7.

Walker, P., Keable, R., Martin, J., Maniatidis, V., 2005. Rammed Earth: Design and Construction Guidelines, first ed. BRE Bookshop, Watford, UK.

Walker, P., Australia, S., 2002. HB 195 - The Australian Earth Building Handbook. Standards Australia International Ltd, Sydney, Australia. 
Walker, P.J., 1995. Strength, durability and shrinkage characteristics of cement stabilised soil blocks. Cement Concrete Comp., 17(4), pp.301-310.

Warren, J., 1999. Conservation of earth structures, first ed. Butterworth Heinemann, British Library, Oxford, UK. 